\title{
Ferroptosis Promotes Microtubule-Associated Protein Tau Aggregation via GSK-3 $\beta$ Activition and Proteasome Inhibition
}

\section{Shaohui Wang}

Central China Normal University

\section{Yao Jiang}

Central China Normal University

Yabo Liu

Central China Normal University

Qianhui Liu

Central China Normal University

\section{Hongwei Sun}

Central China Normal University

\section{Mengjie Mei}

Central China Normal University

Xiaomei Liao ( $\nabla$ liaodebox@mail.ccnu.edu.cn )

College of Life Science, Central China Normal University https://orcid.org/0000-0001-7527-9649

\section{Research Article}

Keywords: Ferroptosis, tau protein, Glycogen synthase kinase-3ß, Ubiquitin proteasome system

Posted Date: November 15th, 2021

DOI: https://doi.org/10.21203/rs.3.rs-1062929/v1

License: (c) (i) This work is licensed under a Creative Commons Attribution 4.0 International License. Read Full License 


\section{Abstract}

Ferroptosis is a form of regulated cell death resulting from iron accumulation and lipid peroxidation. In some particular brain regions, iron dyshomeostasis and peroxidation damage of neurons are closely related to a wide range of neurodegenerative diseases known as "tauopathies", in which intracellular aggregation of microtubule-associated protein tau is the common neuropathological feature. However, the relationship between ferroptosis and tau aggregation is not well understood. The current study demonstrates that erastin-induced ferroptosis can promote tau hyperphosphorylation and aggregation in mouse neuroblastoma cells (N2a cells). Moreover, ferroptosis inhibitor ferrostatin-1 can alleviate tau aggregation effectively. In-depth mechanism research indicates that activated Glycogen synthase kinase$3 \beta$ (GSK-3 $\beta$ ) is responsible for abnormal hyperphosphorylation and accumulation. More importantly, proteasome inhibition can exacerbate the tau degradation obstacle and accelerate tau aggregation in the process of ferroptosis. Our results indicate that ferroptosis can lead to abnormal aggregation of tau protein and might be a promising therapeutic target of tauopathies.

\section{Introduction}

Ferroptosis is a recently discovered form of programmed cell death whose execution requires the accumulation of lipid peroxidation in an iron-dependent manner [1,2]. Ferroptosis is involved in diverse biological contexts and is genetically, biochemically, and morphologically distinct from apoptosis and necrosis. Interestingly, both the iron overload and lipid peroxidation in the brain are also closely related with the characteristic protein aggregation such as tau protein in Alzheimer's disease (AD) and asynuclein in Parkinson's disease (PD), it highlights the associated research aiming at ferroptosis and neurodegenerative disease [3-6].

Tau protein, a highly soluble, microtubule-associated protein, whose primary function is to promote microtubule assembly and stabilization, as well as maintain axonal transport and neuron survival $[7,8]$. As a phosphoprotein, phosphorylation modification can negatively regulate its ability to stimulate microtubule assembly [9]. Moreover, hyperphosphorylation is assumed to be critical for the formation of tau aggregation [10] and alter its degradation through the proteasome or autophagy $[11,12]$. Besides the role in stabilizing neuronal microtubules [13], promoting axonal outgrowth [14], and regulating axonal transport [15], tau also functions to facilitate neuronal iron efflux. Lei et al. have reported that tau deficiency (i.e., the loss of soluble tau) can impair APP-mediated iron export then lead to neurotoxic iron accumulation and neurodegeneration [16,17].

Moreover, the aggregated tau protein in neurofibrillary tangles (NFTs) is associated with the induction of heme oxygenase-1 (HO-1) [18], which can oxidize cellular heme to generate biliverdin, free iron, and carbon monoxide ( $\mathrm{CO}$ ). The released ferrous iron subsequently catalyzes the Fenton reaction to generate high levels of endogenous reactive oxygen species (ROS), which perpetuate the intracellular oxidative stress of the brain $[19,20]$. These reports indicate that tau protein plays a crucial role in regulating cellular iron homeostasis, and tau abnormality is closely related to intracellular iron overload. 
Iron is a crucial participant and regulator of neuronal physiological functions [21]. Iron is an indispensable cofactor for proteins and enzymes required to develop synapses, myelination, and neurotransmitter metabolism [22]. However, iron accumulates in the brain with age, associating with neurodegenerative disorders, including tauopathies such as AD [23]. Interestingly, it was also found that iron overload could induce tau hyperphosphorylation via the dysfunctional insulin signal in primary cultured neurons and mice [24]. Meanwhile, it has been extensively reported that iron overload generates redox-generated free radicals [25], which acts as a pro-oxidant to convert hydrogen peroxide into hydroxyl radicals through the Fenton reaction. The hydroxyl radical then attacks proteins or biological macromolecules [26], results in the formation of oligomeric tau via cysteine-cysteine binding [27] or via kinase pathways [28]. In addition, iron can also produce oligomeric tau by forming intermolecular coordination complexes mediated by phosphorylated amino acid residues $[29,30]$.

All the above researches indicate that intracellular iron accumulation, lipid peroxidation, and tau aggregation are closely related, and a vicious cycle might be formed between iron overload and tau aggregation directly or indirectly by lipid peroxidation. It aroused our interest to unveil the relationship between ferroptosis, the iron-dependent form of regulated necrosis involved in lipid peroxidation, and tau aggregation. To address this directly, we treated N2a neuroblastoma (a neuron-like cell line) with erastin, which could inhibit the activity of cysteine-glutamate antiporter (system $\mathrm{Xc}^{-}$), leading to the depletion of the major cellular antioxidant glutathione (GSH), then decreased the activity of GPX and triggered ferroptosis [31,32]. The relationship between ferroptosis and tau aggregation was explored, with the associated mechanisms investigated in detail. Considering that intracellular iron overload and ROS accumulation play an essential role both in the process of ferroptotic cell death and in the pathogenesis of tau-related neurodegenerative diseases, our study indicates the possible new strategy for tauopathies therapy through the pharmacological interference with the ferroptosis processes of brain issues.

\section{Methods And Materials}

\subsection{Antibodies and reagents}

Rabbit polyclonal antibodies (pAb) against phospho-GSK-3 $\beta$ at Ser9, tau phosphorylated at Ser396, and Thr231 were purchased from Bioworld Technology Inc.( Louis Park, MN, USA). Polyclonal antibodies against LC3 and total GSK-3 $\beta$ were purchased from Cell Signaling Technology, Inc. (Beverly, MA, USA). pAb against $\beta$-actin was obtained from Proteintech Group Inc. (Wuhan, China) and pAb against Ubiquitin and Mouse polyclonal antibodies tau- 5 and UCH-L1 were from Abcam (Cambridge, MA, USA). Vimentin, Goat Anti-Mouse IgG $(\mathrm{H}+\mathrm{L})$ Cy3, and Goat Anti-Rabbit lgG $(\mathrm{H}+\mathrm{L})$ Dylight 488 were purchased from Bioworld Technology Inc.(Louis Park, MN, USA). The specific ferroptosis inducer erastin and inhibitor ferrostatin-1 (Fer-1) were from Med Chem Express (Shanghai, China). Cell culture media were from Gibco Life Technologies (Grand Island, NY, USA).

\subsection{Cell culture and drug treatments}


Mouse neuroblastoma Neuro2a (N2a) cells were cultured in a $5 \% \mathrm{CO}_{2}$ humidified incubator at $37^{\circ} \mathrm{C}$ with a medium consisting of $45 \%$ Dulbecco's modified Eagle's medium (DMEM), 45\% Opti-MEM supplemented with $10 \%(\mathrm{v} / \mathrm{v})$ fetal bovine serum. For drug treatment, 5, 10 and $20 \mu \mathrm{M}$ erastin were used to treat cells for 6 and $12 \mathrm{hr}$ to induce ferroptosis. During the incubation with $10 \mu \mathrm{M}$ erastin, cells were either treated or not treated with 1, 2 and $4 \mu \mathrm{M}$ ferroptosis inhibitor Ferrostatin- 1 for 6 and $12 \mathrm{hr}$. The cells were treated with $0.2 \%$ dimethyl sulfoxide (DMSO) as a control.

\subsection{Cell viability analysis}

Cell Counting Kit-8 (Beyotime Institute of Biotechnology, Jiangsu, China) was used to determine cell viability. In brief, cells were seeded in 96-cell micro-culture plate at an initial density of 5000 cells per well and allowed to grow for $48 \mathrm{~h}$ in an incubator maintained at $37^{\circ} \mathrm{C}$. The cells were treated with corresponding drugs for 6 and $12 \mathrm{hr}$ respectively, then $10 \mu \mathrm{L}$ reagent was added to each well, and cells were incubated in the incubator for $2 \mathrm{hr}$. Finally, the plates were scanned with a microplate reader (BioRad, Hercules, CA, USA) at $450 \mathrm{~nm}$ to measure the absorbance.

\subsection{Intracellular glutathione peroxidase (GPX), reactive oxygen species (ROS), and iron content detection}

Following drug treatment, cells were washed once with cold PBS. They were lysed directly in an Eppendorf tube with lysis buffer $(50 \mathrm{mM}$ Tris- $\mathrm{HCl}, 150 \mathrm{mM} \mathrm{NaCl}, 0.1 \%$ sodium dodecyl sulfate(SDS), $1 \%$ Nonidet P-40, $0.5 \%$ sodium deoxycholate, $0.02 \% \mathrm{NaN}_{3}, 100 \mu \mathrm{g} / \mathrm{ml}$ phenylmethylsulfonyl fluoride, $2 \mu \mathrm{g} / \mathrm{ml}$ Aprotinin) for $30 \mathrm{~min}$ and centrifugation for $15 \mathrm{~min}$ at $12000 \mathrm{xg}$. The supernatant was removed, and protein concentration was determined. The relative indicators were then measured using commercial assay kits. In brief, the ROS levels were measured by adding $100 \mu \mathrm{L}$ of protein supernatant and $100 \mu \mathrm{L}$ of 2'7'-dichlorofluorescein diacetate (DCFH-DA) to a 96-well plate, which was incubated for $10 \mathrm{~min}$ at $37^{\circ} \mathrm{C}$ in the dark. Fluorescence detection was then carried out using an excitation wavelength of $488 \mathrm{~nm}$ and an emission wavelength of $525 \mathrm{~nm}$. GPX and iron levels were assessed following the manufacturer's instruction (Nanjing Jiancheng Bioengineering Institute, Nanjing, China), and the samples were incubated for $30 \mathrm{~min}$ at room temperature. The absorbance was measured at $340 \mathrm{~nm}$ to calculate the GPX level and calculate the iron content at $590 \mathrm{~nm}$.

\subsection{Cell morphology observation}

N2a cells were seeded in the 24-well plate. When cells grew to $80 \%$ abundance, they were treated with erastin, erastin plus ferrostatin-1 for 6 and $12 \mathrm{hr}$, respectively. The morphology of the N2a cells with different treatments was observed using a phase-contrast microscope as in our previous study [33]. The obtained images were processed with image processing software, Image $\mathrm{J}$, where neurites were manually traced with a Wacom tablet to measure the length. Average lengths of the neurites were then obtained by dividing the total length by the number of neurons measured.

\subsection{Western Blot}


Cells were seeded in six-well plates and treated as described above. The protein concentration was determined using the BCA protein assay. For Western blot analysis, twenty micrograms of total protein were separated using $10 \%$ SDS polyacrylamide gels and then transferred by electroblotting onto polyvinylidene difluoride membranes. After the membranes were blocked with $5 \%$ nonfat milk for $1 \mathrm{hr}$, washing the membranes three times with PBS (containing $0.1 \%$ Tween-20) for 10 min each time. Membranes were probed overnight at $4{ }^{\circ} \mathrm{C}$ with antibodies. The immunoblots were washed and treated with the appropriate species of horseradish peroxidase (HRP)-conjugated secondary antibody at $37^{\circ} \mathrm{C}$ for $1 \mathrm{hr}$ and then wash the membranes three times with PBS. The immunoreactive bands were quantified using an Infrared Imaging System.

\subsection{Immunofluorescence cytochemistry}

N2a cells were mounted on coverslips in a 24-well plate. After drug treatment, cells were fixed with Precooled methanol for $10 \mathrm{~min}$ at $-20^{\circ} \mathrm{C}$. After washing with $0.2 \%$ Triton-PBS and $0.5 \%$ Triton-PBS, respectively for three times, cells were incubated for $1 \mathrm{hr}$ in blocking buffer ( $5 \% \mathrm{BSA})$, followed by incubation for 48 hours with primary antibodies at $4{ }^{\circ} \mathrm{C}$ (tau-5, 1:100; vimentin, 1:100). The coverslips were then washed three times with $0.1 \%$ Triton-PBS and incubated in the second antibody for $1 \mathrm{hr}$ at 37 ${ }^{\circ} \mathrm{C}$. The coverslips were counterstained with Hoechst and washed three times with Triton-PBS. Finally, cells on the coverslips were observed and imaged using a fluorescence microscope.

\subsection{Measurement of 20S Proteasome Activity}

According to the manufacturer's instructions and our previous literature [34], the 20S proteasome catalytic core chymotrypsin-like activity kit was measured using the $20 \mathrm{~S}$ proteasome activity assay kit (Boston Biochem, Cambridge, MA, USA). In brief, following the above drug treatment, the cells were collected, resuspended with the $20 \mathrm{~S}$ proteasome assay buffer, then centrifuged at $8000 \times \mathrm{g}$ for $8 \mathrm{~min}$, and the precipitation was collected. The precipitation was treated with the $20 \mathrm{~S}$ proteasome lysis buffer for 30 min at room temperature. The cytosolic extract was subsequently collected as the supernatant following centrifugation for $12 \mathrm{~min}$ at $12000 \times \mathrm{g}$. For the proteasome activity assay, the cell lysates were incubated with chymotrypsin fluorogenic substrate Suc-Leu-Leu-Val-Tyr-AMC. The chymotrypsin-like activity was determined to increase of the fluorescence intensity in the reaction products by using the Synergy 2 MultiMode Microplate Reader (Bio Tek, Winooski, VT, USA) at $360 \mathrm{~nm}$ excitation and $480 \mathrm{~nm}$ emission wavelengths [35].

\subsection{Immunoprecipitation}

Cells were seeded in six-well plates and treated as described above. After one wash with cold PBS, the cells were lysed directly with RIPA lysis buffer (50 mM Tris-HCL, $150 \mathrm{mM} \mathrm{NaCl}, 5 \mathrm{mM}$ EDTA, 1\% Triton-X, $1 \%$ DOC, $0.1 \%$ SDS, $0.2 \mathrm{mM}$ TPCK, $1 \mathrm{mM} \mathrm{PMSF}, 2 \mathrm{mM}$ TLCK) for $30 \mathrm{~min}$ on ice, and centrifuged at 12000 $\times \mathrm{g}$ for 20 min subsequently. Add protein $\mathrm{G}$ to the supernatant at a ratio of 100:1 between the supernatant and protein $\mathrm{G}$, and shake it slowly on a shaker at $4{ }^{\circ} \mathrm{C}$ for $30 \mathrm{~min}$ to remove non-specific protein binding. After centrifugation at $12000 \times \mathrm{g}$ for $15 \mathrm{~min}$, an anti-tau- 5 antibody was added to the sample according to 
the antibody ratio to sample at 1:100 and incubated overnight on a shaker at $4{ }^{\circ} \mathrm{C}$. After incubating the primary antibody overnight, add protein $\mathrm{G}$ at a ratio of $5: 1$ between the supernatant and protein $\mathrm{G}$, slowly incubate in a low-temperature studio for $2 \mathrm{hr}$ and resuspend the pellet in loading buffer. After boiling for $10 \mathrm{~min}$ and centrifuging at $12000 \times \mathrm{g}$ for $1 \mathrm{~min}$, the protein concentration was determined using the BCA protein assay.

\subsection{Statistics Analysis}

All experiments were performed in triplicate. Data were expressed as mean $\pm S D$ and analyzed using SPSS 27.0 statistic software. The One-Way ANOVA procedure followed by LSD's post hoc tests was used to determine the different means between groups $(p<0.05)$.

\section{Results}

\subsection{Erastin decreases the viability of N2a cells}

To determine the effect of the ferroptosis inducer erastin on the viability of N2a cells, we treated N2a cells with different concentrations of erastin for 6 and $12 \mathrm{hr}$. It was shown that the cell viability decreased in a concentration and time-dependent manner following erastin treatment. Compared to the control group, 5, 10 and $20 \mu \mathrm{M}$ erastin treatment for $6 \mathrm{hr}$ decreased the relative cellular viability by $7.35 \%, 12.72 \%$ and $12.24 \%$, respectively. What's more, the relative cell viability decreased by $17.21 \%, 24.53 \%$ and $24.77 \%$, respectively, when cells were treated with 5,10 and $20 \mu \mathrm{M}$ erastin for $12 \mathrm{hr}$ (Fig. 1A). As there was no significant difference in the activity inhibition between the concentrations of $10 \mu \mathrm{M}$ and $20 \mu \mathrm{M}$, we selected $10 \mu \mathrm{M}$ erastin as the optimal treatment concentration in the subsequent experiments. We also found that 2 or $4 \mu \mathrm{M}$ ferrostatin-1 (Fer-1) treatment, an effective inhibitor of ferroptosis, which can inhibit the accumulation of ROS then inhibit oxidative lipid damage and cell death [36], can effectively reverse erastin induced cell viability inhibition (Fig. 1B).

\subsection{Erastin treatment induces intracellular ROS accumulation and iron overload in N2a cells}

Erastin can induce system $\mathrm{Xc}^{-}$inhibition and cysteine deprivation, then lead to GSH deletion and GPX inactivation, finally initiating ferrotosis in many cell types. To confirm the sensitivity of N2a cells to erastin-induced ferroptosis, we assayed the intracellular GPX activity, ROS level and iron content after erastin treatment.

The results showed that compared with the control group, N2a cells treated with $10 \mu \mathrm{M}$ erastin resulted in a significant decrease of intracellular GPX activity after 6 (Fig. 2A) and $12 \mathrm{hr}$ (Fig. 2B). Meanwhile, the ROS content (Fig. 2C, 2D) and iron levels increased significantly (Fig. 2E, 2F). The results also demonstrated that $2 \mu \mathrm{M}$ ferrostatin- 1 treatment could significantly reverse erastin induced GPX, ROS and iron imbalance. These results confirmed that erastin could induce ferroptotic cell death in N2a cells.

\subsection{Erastin treatment caused morphological abnormality of N2a cells}


The unique ability of neurons is to compute and allocate massive information, which relies on their polarized morphology. Damage factors such as peroxidation can cause microtubule depolymerization and neuron death [37]. Therefore, we observed the morphology changes of N2a cells following erastin exposure by using phase-contrast microscopy.

To the DMSO treated cells, the cell bodies showed tapered or with clear edges, and the neurites were stretched. However, after erastin treatment for 6 and $12 \mathrm{hr}$, the cell bodies became round, and the neurites retracted obviously (Fig. 3A). Compared with the erastin treatment group, the cell bodies of the erastin plus ferrostatin-1 co-treatment group recovered the polarity gradually. Most of the cell bodies were tapered, and the length of the neurites partially increased (Fig. 3B). The above results showed that erastin exposure could dramatically destroy the microtubule structure and inhibit the neurite outgrowth in N2a cells.

\subsection{Erastin induced abnormal aggregation of tau protein}

The microtubule is a major cytoskeletal component of neurites, and the regulation of microtubule stability is essential for neurite morphogenesis. Microtubule-associated protein tau plays a crucial role in establishing cell polarity and maintaining microtubule stability [38]. The dissociation of tau from microtubules would impede the microtubule assembly and disrupt the stability of the microtubule network, then destroy the process of axonal transport and synaptic plasticity. Meanwhile, the dissociated tau would self-aggregate and form intracellular inclusions. Based on the result that erastin treatment destroyed cytoskeleton structure significantly, to clarify whether the abnormality of neuronal morphology is related to tau protein, we double-stained the cells with antibody tau- 5 (identified total tau) and vimentin (a known marker of aggregate-forming protein).

After N2a cells were treated with erastin for 6 and $12 \mathrm{hr}$, tau protein aggregated obviously around the nucleus (Fig. 4A and 4B. e, red), the strongly positive staining of vimentin (Fig. 4A and 4B. f, green) indicated that erastin could lead to the formation of intracellular protein aggregates. Furthermore, the colocalization of tau protein (red) and vimentin (green) around the nucleus suggested that the aggregates contain tau protein (Fig. 4A and 4B. h, orange). It was also shown that the aggregated tau protein disappeared when cells were treated with erastin plus ferrostatin-1(Fig. 4A and 4B. I, orange). The above results demonstrate that erastin treatment would induce abnormal aggregation of tau protein in the cytoplasm.

\subsection{Erastin remarkably increases the content of total tau and phosphorylated tau}

Tau function and affinity for the microtubules mainly depend on its phosphorylation status. Hyperphosphorylation of tau protein at some key sites such as Ser396 and Thr231 can decrease the affinity between tau and microtubules, then cause the dissociation of tau from microtubules and the formation of intracellular tau aggregates $[39,40]$. In the present study, we detect the content of total tau and phosphorylated tau at Ser396 and Thr231 sites by Western blot (Fig. 5). It was shown that after erastin treatment for 6 and $12 \mathrm{hr}$, the intracellular total tau increased significantly. Meanwhile, the relative 
level of phosphorylated tau at Ser396 and Thr231 sites also upregulated dramatically, especially in the 6 hr erastin treatment group.

Interestingly, $2 \mu \mathrm{M}$ ferrostatin-1 could effectively reverse erastin induced increase of total tau and phosphorylated tau. Statistical analysis revealed a positive correlation between the ROS content and the iron level $(r=0.65)$, and we also found ROS induced a highly positive correlation with tau phosphorylation at Ser396 ( $r=0.82)$ and Thr231 sites ( $r=0.76)$ (Fig. 6l). These results indicate that during neuronal ferroptosis, tau was hyperphosphorylated at Ser396 and Thr231 sites.

\subsection{Erastin activated GSK-3 $\beta$ in N2a cells}

Most studies on tau hyperphosphorylation explored the kinase-phosphatase imbalance and regarded GSK-3 $\beta$ as the significant kinase involved in tau pathology [41]. GSK-3 $\beta$ mediated tau phosphorylation is observed in areas that are in close proximity to the microtubule-binding domains and their amino acid residues [42]. Therefore, the hyperphosphorylated tau induced by GSK-3 $\beta$ is prone to dissociate from microtubules and self-aggregate in the cytoplasma [43]. Given that GSK-3 $\beta$ is one of the most important kinases that regulate tau phosphorylation at Ser396 and Thr231 sites [44], to clarify the underlying mechanisms of tau hyperphosphorylation in the process of erastin-induced ferroptosis, we detected the level of total GSK-3 $\beta$ and Ser-9-phosphorylated GSK-3 $\beta$ (negative related to GSK-3 $\beta$ activity). As shown in Figures $6 \mathrm{~A}$ and $6 \mathrm{C}$, after 6 and $12 \mathrm{hr}$ erastin exposure, the total level of GSK-3 $\beta$ showed no significant

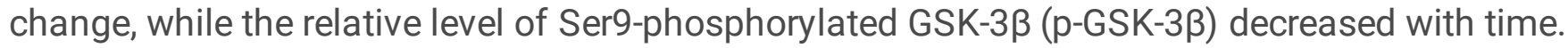
Compared to the control group, the relative phosphorylated GSK-3 $\beta$ at Ser9 decreased to 40\% and 30\%, respectively. Meanwhile, $2 \mu \mathrm{M}$ ferrostatin- 1 treatment effectively rescued erastin induced GSK-3 $\beta$ activity upregulation. These results suggest that GSK-3 $\beta$ activation is involved in the erastin induced tau hyperphosphorylation in N2a cells.

\subsection{Effect of erastin on the content of Poly-Ub and Mono-Ub}

Based on the above results that erastin treatment produces tau aggregates (Fig. 4) and elevates the total tau level (Fig. 5), we wonder whether degradation impairment contributes to erastin induced tau accumulation. Intracellular misfolded proteins that fail to be rescued by molecular chaperones are sent for degradation by proteasome and autophagy. The recognition signal for degradation of aggregated proteins by both the proteasome and autophagy is driven by polyubiquitin chain labeling of substrates [45] which depends on the ubiquitin pool homeostasis. To determine whether the metabolic abnormality of tau protein is associated with the ubiquitin cycle, we first detected the content of polyubiquitin (Poly-Ub) and monomer ubiquitin (Mono-Ub) in N2a cells. It was shown that after the erastin treatment for 6 and $12 \mathrm{hr}$, the intracellular poly-Ub level increased significantly, while the level of mono-Ub decreased obviously (Fig. 7A, 7D). We also observed that ferrostatin-1 treatment could successfully reverse erastin induced ubiquitin cycle impairment. The above results indicate that during the process of erastin induced ferroptotic cell death, the degradation of polyubiquitin-labeled substrates was inhibited. 


\subsection{Erastin induced abnormal ubiquitination modification of tau protein}

As pathologically modified proteins such as hyperphosphorylated tau can be degraded by ubiquitinproteasome system [46] and autophagy-lysosome pathway [47], and polyubiquitin label is the prerequisite of proteins degradation by these two systems. In view of the significant down-regulation of monomer ubiquitin and apparent up-regulation of poly-ubiquitin after erastin treatment, we further tested the effect of erastin on the ubiquitination of tau by immunoprecipitation. Following incubating with the tau- 5 antibody (analyzed total tau proteins), the samples from different treatment groups were used for immunoblot analysis with tau- 5 and anti-ubiquitin antibody (probed ubiquitination-conjugated proteins). It was shown that compared to the control group, the ubiquitinated tau increased significantly, most so with $6 \mathrm{hr}$ erastin treatment (Fig. 8). Moreover, ferrostatin-1 could rescue erastin induced association abnormality between ubiquitin and tau protein. The above results indicate that erastin can cause polyubiquitinated tau protein degradation impairment, which may be involved in the abnormal aggregation of tau.

\subsection{Erastin treatment inhibited $20 \mathrm{~S}$ proteasome activity in N2a cells}

The proteasome is the main route for misfolded proteins degradation, and the $20 \mathrm{~S}$ proteasome is a complex containing activities similar to trypsin, chymotrypsin, and caspase. As chymotrypsin-like activity inhibition can cause the protein degradation efficiency of the proteasome to be significantly reduced [48], we focused on the chymotrypsin-like activity alteration of the proteasome after erastin treatment. Figure 9 shown that chymotrypsin activity decreased significantly in a time-dependent manner after 6 and $12 \mathrm{hr}$ erastin treatments, and $2 \mu \mathrm{M}$ ferrostatin- 1 dramatically mitigated erastin induced proteasome activity down-regulation. The above results indicate that the activity of the proteasome system is inhibited during ferroptosis and might be contributing the tau aggregation.

\subsection{Erastin treatment activated the autophagy pathway}

Considering that the autophagy-lysosomal system can also degrade abnormally aggregated tau protein and a lipidated form of LC3, LC3-II, is an autophagosomal marker in mammals, we further analyzed the

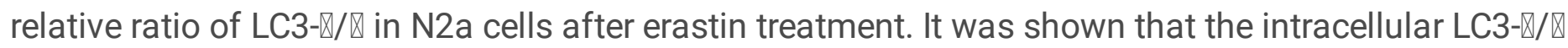
ratio increased about $10 \%$ at $6 \mathrm{hr}$ and $20 \%$ at $12 \mathrm{hr}$ than the controls and showed clear time-dependence (Fig. 10). The above results indicated that in the first 12 hours of erastin treatment, proteasome activity is inhibited. However, the autophagy-lysosome system is compensatively activated to maintain intracellular protein balance. But, obviously, the activation of the autophagy-lysosome system is insufficient to degrade the abnormally aggregated tau protein.

\section{Discussion}

Abnormal deposition of aggregated microtubule-associated protein tau is a common final pathway of tau-related neurodegenerative diseases named "tauopathies", including Alzheimer's disease(AD), progressive supranuclear palsy (PSP), Huntington disease (HD), frontotemporal dementia with 
parkinsonism-17 (FTDP-17), and so on. It clarified that the factors that promote tau aggregation are important to elucidate the pathogenesis and acquire a good curative effect of these diseases. Iron has been shown to promote aggregation of some neurodegenerative diseases characteristic aberrant proteins, such as tau $[49,50]$ and $\beta$-amyloid [51]. Further support for the involvement of iron in the pathogenesis of tauopathies is provided by the recent discovery of a new form of cell death, ferroptosis. Arising from iron-dependent lipid peroxidation, ferroptosis is augmented in conditions of cysteine depletion and glutathione peroxidase (GPX) inactivation $[20,52,53,26]$. What's more, it has been widely observed that many neurodegenerative diseases such as $A D$ are pathologically characterized by the accumulation of iron in the brain and peroxidation damage of neurons [54]. However, the detailed relation between ferroptosis and abnormal tau aggregation is still unclear.

In the present study, ferroptotic cell death was constructed by treating N2a cells with ferroptosis inducer erastin for $6 \mathrm{hr}$ and $12 \mathrm{hr}$. It was shown that erastin exposure significantly inhibited the viability of N2a cells, prominently decreased the intracellular GPX activity (a key marker of ferroptosis),elevated ROS and iron content. What's more, $2 \mu \mathrm{M}$ ferroptosis inhibitor ferrostatin- 1 can effectively rescue the cytotoxic effect caused by erastin. The above results confirm that erastin can induce ferroptosis in N2a cells. Meanwhile, it was also found that erastin treatment caused noticeable morphology change of N2a cells, especially significantly shortened neurites, which means the neuronal skeletal system was impaired during ferroptosis. As tau protein is one of the most important microtubule-related proteins in neurons and plays a key role in maintaining the stability of the neuronal skeletal system $[2,55,56]$, the dissociation of tau from microtubules can induce not only the collapse of cytoskeletal structure but also the formation of intracellular tau aggregates. Naturally, the obvious neurites retraction aroused our interest to assay the status of tau protein during ferroptosis. Interestingly, the immunofluorescence cytochemistry results showed clear tau-positive aggregates in the cytoplasm after erastin treatment, and it directly demonstrated the causal relationship between ferroptosis and abnormal tau aggregation.

Based on the above results, we further explored the mechanisms involved in tau aggregation during ferroptosis. It was accepted widely that several post-translational modifications were proposed to play important roles in tau aggregation [57]. Among them, phosphorylation modification can negatively regulate the ability of tau to stimulate microtubule assembly [9]. It was reported that phosphorylation of tau at the Thr231 site could lead to a trans-to-cis conformational change trigger the detachment of tau from microtubules [58]. Likewise, phosphorylation of tau at Ser396 reduces its affinity for MTs and its ability to stabilize MTs against depolymerization [59]. Thus, we assayed the phosphorylation profile of Thr231 and Ser396 sites. It was found that compared to the control group, the phosphorylation modification levels of tau protein at Ser396 and Thr231 sites increased significantly after erastin treatment for 6 and $12 \mathrm{hr}$. Considering the equilibrium disruption between tau kinase and phosphatase activities is the major reason responsible for the hyperphosphorylation of tau protein, we further measured the content and activity of GSK-3 $\beta$, a crucial tau kinase corresponding to $70 \%$ of tau pathological phosphorylation sites including Ser396 and Thr231 sites [60]. We found that the level of GSK-3 $\beta$ was not significantly changed after erastin treatment, but the reduction of phosphorylated GSK$3 \beta$ at Ser9 suggested that erastin could induce GSK-3 $\beta$ activation. 
Interestingly, Wu et al. also found that GSK-3 $\beta$ silence can block erastin-induced ferroptosis with less production of ROS, and GSK-3 $\beta$ overexpression can exacerbate erastin induced ferroptosis in breast cancer cells [45]. These results clearly demonstrate the relationship between ferroptosis and GSK-3 $\beta$ activation. Considering that GSK-3 $\beta$ dysregulation almost influences all the major hallmarks of tauopathies, including tau hyperphosphorylation and aggregation [42,61,62], synaptic dysfunction, and memory impairment [63], clarifying its contribution to the ferroptosis will be the central objectives of further study and may provide a viable therapeutic approach to prevent or halt tauopathies.

Erastin induced tau aggregation strongly indicated a concomitant loss of proteostasis, which is maintained by several systems in the cell, including the ubiquitin proteasome system (UPS) and autophagy-lysosome system. Given the two protein degradation pathways both required ubiquitin label of substrates [64-67], we first assayed the content change of poly-ubiquitin and mono-Ub after erastin treatment and found that intracellular poly-ubiquitin obviously increased, but the level of mono-Ub decreased significantly. Moreover, erastin treatment increased the amount of ubiquitinated tau protein significantly. These results suggested that ferroptosis would lead to tau degradation impairment.

As the ubiquitin-proteasome system is the principal route for the degradation of intracellular misfolded or damaged proteins [68], including tau protein [69], we further explored the mechanistic research and found that chymotrypsin-like activity of $20 \mathrm{~S}$ proteasome, which directly affects the degradation efficiency of the proteasome [48], decreased in a time-dependent manner after erastin treatment. As proteasome cannot adequately handle misfolded protein aggregates [70], what's more, aggregates of some pathogenic proteins can directly inhibit proteasome activity [71]. These data together suggested that in the process of ferroptosis, hyperphosphorylated tau can't be effectively degraded by the proteasome system and even can induce proteasome activity inhibition.

In addition to the proteasome, autophagy also plays an important role in removing aggregated proteins [72,73], including tau proteins [74]. But whether autophagy is involved in tau clearance during erastin-induced ferroptosis is not demonstrated. LC3-I and LC3-II are two important biomarkers in autophagy, the conversion of LC3-I to LC3-II indicates autophagy activation [75]. In this study, the

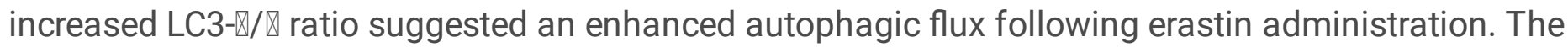
founding is consistent with previous studies that erastin induced LC3 conversion and autophagy activation [76]. Since there is a contradiction between autophagy activation and tau accumulation in the process of erastin-induced ferroptosis, we consider that proteasome inhibition might play a more critical part than autophagy in the pathological aggregation of tau protein.

In conclusion, our data suggest that in the process of erastin-induced ferroptotic cell death, microtubuleassociated protein tau undergoes hyperphosphorylation and aggregation. The pathological changes of tau are related to the activation of GSK-3 $\beta$ and the inhibition of the proteasome system (Fig. 11). It provides a clear clue about the relationship between ferroptosis and tau aggregation, opens new therapeutic targets and strategies for tauopathies. 


\section{Declarations}

\section{Conflict of interest statement}

No potential conflicts of interest relevant to this article were reported.

\section{Ethics approval}

This experiment was approved by the Ethics Committee of Central China Normal University.

\section{Consent to participate}

Not applicable

\section{Consent for publication}

Not applicable.

\section{Availability of data and materials}

The data are available upon reasonable request from the author for correspondence.

\section{Funding}

This work was supported by the project of Hubei Key Laboratory of Genetic Regulation and Integrative Biology (No. GRIB201905) and National Natural Science Foundation of China (No. 81771150, 22076061 and 41601543).

\section{Authors' contributions}

$\mathrm{XM}-\mathrm{L}$ conceived the experiments and supervised the project. YJ and YB-L performed the experiments. SH$W$ collected the data, made the figures and wrote the manuscript. MJ-M did the analysis. HW-S contributed essential reagents or tools. All authors read and approved the final manuscript.

\section{Author information}

Shaohui Wang, Yao Jiang,Yabo Liucontributed equally to this study

\section{Acknowledgments}

We thank all the members of our research team for their help and support from School of Life Sciences, Central China Normal University.

\section{References}


1. Dixon SJ, Lemberg KM, Lamprecht MR, Skouta R, Zaitsev EM, Gleason CE, Patel DN, Bauer AJ, Cantley AM, Yang WS, Morrison B 3, Stockwell BR (2012) Ferroptosis: an iron-dependent form of nonapoptotic cell death. Cell 149(5):1060-1072. https://doi.org/10.1016/j.cell.2012.03.042

2. Yang WS, Stockwell BR (2016) Ferroptosis: Death by Lipid Peroxidation. Trends Cell Biol 26(3):165176. https://doi.org/10.1016/j.tcb.2015.10.014

3. Jellinger KA (1999) The role of iron in neurodegeneration: prospects for pharmacotherapy of Parkinson's disease. Drugs Aging 14(2):115-140. https://doi.org/10.2165/00002512-19991402000004

4. Zhang GM, Zhang YR, Shen YX, Wang YC, Zhao M, Sun L (2021) The Potential Role of Ferroptosis in Alzheimer's Disease. J Alzheimers Dis 80(3):907-925. https://doi.org/10.3233/jad-201369

5. Logroscino G, Marder K, Graziano J, Freyer G, Slavkovich V, Lolacono N, Cote L, Mayeux R (1997) Altered systemic iron metabolism in Parkinson's disease. Neurology 49(3):714-717. https://doi.org/10.1212/wnl.49.3.714

6. Chiueh CC (2001) Iron overload, oxidative stress, and axonal dystrophy in brain disorders. Pediatr Neurol 25(2):138-147. https://doi.org/10.1016/s0887-8994(01)00266-1

7. Fulga TA, Elson-Schwab I, Khurana V, Steinhilb ML, Spires TL, Hyman BT, Feany MB (2007) Abnormal bundling and accumulation of F-actin mediates tau-induced neuronal degeneration in vivo. Nat Cell Biol 9(2):139-U117. https://doi.org/10.1038/ncb1528

8. Johnson GV, Hartigan JA (1999) Tau protein in normal and Alzheimer's disease brain: an update. J Alzheimers Dis 1(4-5):329-351. https://doi.org/10.3233/jad-1999-14-512

9. Lindwall G, Cole RD (1984) Phosphorylation affects the ability of tau protein to promote microtubule assembly. J Biol Chem 259(8):5301-5305

10. Mandelkow EM, Mandelkow E (2012) Biochemistry and cell biology of tau protein in neurofibrillary degeneration. Cold Spring Harb Perspect Med 2(7):a006247. https://doi.org/10.1101/cshperspect.a006247

11. Guillozet-Bongaarts AL, Cahill ME, Cryns VL, Reynolds MR, Berry RW, Binder LI (2006) Pseudophosphorylation of tau at serine 422 inhibits caspase cleavage: in vitro evidence and implications for tangle formation in vivo. J Neurochem 97(4):1005-1014. https://doi.org/10.1111/j.1471-4159.2006.03784.x

12. Dickey CA, Kamal A, Lundgren K, Klosak N, Bailey RM, Dunmore J, Ash P, Shoraka S, Zlatkovic J, Eckman CB, Patterson C, Dickson DW, Nahman NS Jr, Hutton M, Burrows F, Petrucelli L (2007) The high-affinity HSP90-CHIP complex recognizes and selectively degrades phosphorylated tau client proteins. J Clin Invest 117(3):648-658. https://doi.org/10.1172/jci29715

13. Feinstein SC, Wilson L (2005) Inability of tau to properly regulate neuronal microtubule dynamics: a loss-of-function mechanism by which tau might mediate neuronal cell death. Biochim Biophys Acta 1739(2-3):268-279. https://doi.org/10.1016/j.bbadis.2004.07.002

14. Caceres A, Kosik KS (1990) Inhibition of neurite polarity by tau antisense oligonucleotides in primary cerebellar neurons. Nature 343(6257):461-463. https://doi.org/10.1038/343461a0 
15. Magnani E, Fan J, Gasparini L, Golding M, Williams M, Schiavo G, Goedert M, Amos LA, Spillantini MG (2007) Interaction of tau protein with the dynactin complex. Embo j 26(21):4546-4554. https://doi.org/10.1038/sj.emboj.7601878

16. Lei P, Ayton S, Appukuttan AT, Moon S, Duce JA, Volitakis I, Cherny R, Wood SJ, Greenough M, Berger G, Pantelis C, McGorry P, Yung A, Finkelstein DI, Bush Al (2017) Lithium suppression of tau induces brain iron accumulation and neurodegeneration. Mol Psychiatry 22(3):396-406. https://doi.org/10.1038/mp.2016.96

17. Lei P, Ayton S, Finkelstein DI, Spoerri L, Ciccotosto GD, Wright DK, Wong BX, Adlard PA, Cherny RA, Lam LQ, Roberts BR, Volitakis I, Egan GF, McLean CA, Cappai R, Duce JA, Bush Al (2012) Tau deficiency induces parkinsonism with dementia by impairing APP-mediated iron export. Nat Med 18(2):291-295. https://doi.org/10.1038/nm.2613

18. Perry G, Nunomura A, Hirai K, Zhu X, Prez M, Avila J, Castellani RJ, Atwood CS, Aliev G, Sayre LM, Takeda A, Smith MA (2002) Is oxidative damage the fundamental pathogenic mechanism of Alzheimer's and other neurodegenerative diseases? Free Radical Bio Med 33(11):1475-1479. https://doi.org/https://doi.org/10.1016/S0891-5849(02)01113-9

19. Zukor H, Song W, Liberman A, Mui J, Vali H, Fillebeen C, Pantopoulos K, Wu TD, Guerquin-Kern JL, Schipper HM (2009) HO-1-mediated macroautophagy: a mechanism for unregulated iron deposition in aging and degenerating neural tissues. J Neurochem 109(3):776-791. https://doi.org/10.1111/j.1471-4159.2009.06007.x

20. Ward RJ, Zucca FA, Duyn JH, Crichton RR, Zecca L (2014) The role of iron in brain ageing and neurodegenerative disorders. Lancet Neurol 13(10):1045-1060. https://doi.org/10.1016/s14744422(14)70117-6

21. Salvador GA (2010) Iron in neuronal function and dysfunction. BioFactors 36(2):103-110. https://doi.org/10.1002/biof.80

22. Carpenter KLH, Li W, Wei H, Wu B, Xiao X, Liu C, Worley G, Egger HL (2016) Magnetic susceptibility of brain iron is associated with childhood spatial IQ. Neurolmage 132:167-174. https://doi.org/10.1016/j.neuroimage.2016.02.028

23. Zhang G, Zhang Y, Shen Y, Wang Y, Zhao M, Sun L (2021) The Potential Role of Ferroptosis in Alzheimer's Disease. J Alzheimers Dis 80(3):907-925. https://doi.org/10.3233/jad-201369

24. Wan W, Cao L, Kalionis B, Murthi P, Xia S, Guan Y (2019) Iron Deposition Leads to Hyperphosphorylation of Tau and Disruption of Insulin Signaling. Front Neurol 10:607. https://doi.org/10.3389/fneur.2019.00607

25. Smith MA, Harris PL, Sayre LM, Perry G (1997) Iron accumulation in Alzheimer disease is a source of redox-generated free radicals. Proc Natl Acad Sci U S A 94(18):9866-9868. https://doi.org/10.1073/pnas.94.18.9866

26. Huang X, Atwood CS, Hartshorn MA, Multhaup G, Goldstein LE, Scarpa RC, Cuajungco MP, Gray DN, Lim J, Moir RD, Tanzi RE, Bush Al (1999) The A beta peptide of Alzheimer's disease directly produces 
hydrogen peroxide through metal ion reduction. Biochemistry 38(24):7609-7616. https://doi.org/10.1021/bi990438f

27. Soeda Y, Yoshikawa M, Almeida OF, Sumioka A, Maeda S, Osada H, Kondoh Y, Saito A, Miyasaka T, Kimura T, Suzuki M, Koyama H, Yoshiike Y, Sugimoto H, Ihara Y, Takashima A (2015) Toxic tau oligomer formation blocked by capping of cysteine residues with 1,2-dihydroxybenzene groups. Nat Commun 6:10216. https://doi.org/10.1038/ncomms10216

28. Uranga RM, Giusto NM, Salvador GA (2009) Iron-induced oxidative injury differentially regulates $\mathrm{PI3K} /$ Akt/GSK3beta pathway in synaptic endings from adult and aged rats. Toxicol Sci 111(2):331344. https://doi.org/10.1093/toxsci/kfp152

29. Bader B, Nübling G, Mehle A, Nobile S, Kretzschmar H, Giese A (2011) Single particle analysis of tau oligomer formation induced by metal ions and organic solvents. Biochem Biophys Res Commun 411(1):190-196. https://doi.org/10.1016/j.bbrc.2011.06.135

30. Nübling G, Bader B, Levin J, Hildebrandt J, Kretzschmar H, Giese A (2012) Synergistic influence of phosphorylation and metal ions on tau oligomer formation and coaggregation with a-synuclein at the single molecule level. Mol Neurodegener 7:35. https://doi.org/10.1186/1750-1326-7-35

31. Perry G, Nunomura A, Hirai K, Zhu X, Pérez M, Avila J, Castellani RJ, Atwood CS, Aliev G, Sayre LM, Takeda A, Smith MA (2002) Is oxidative damage the fundamental pathogenic mechanism of Alzheimer's and other neurodegenerative diseases? Free Radic Biol Med 33(11):1475-1479. https://doi.org/10.1016/s0891-5849(02)01113-9

32. Schipper HM, Bennett DA, Liberman A, Bienias JL, Schneider JA, Kelly J, Arvanitakis Z (2006) Glial heme oxygenase-1 expression in Alzheimer disease and mild cognitive impairment. Neurobiol Aging 27(2):252-261. https://doi.org/10.1016/j.neurobiolaging.2005.01.016

33. Wang S, Zhang P, Liu R, Li Y, Liu C, Liao X (2017) A DEHP plasticizer alters synaptic proteins via peroxidation. Toxicol Res (Camb) 6(1):89-97. https://doi.org/10.1039/c6tx00361c

34. Xie M, Li Y, Wang SH, Yu QT, Meng X, Liao XM (2017) The Involvement of NR2B and tau Protein in MG132-Induced CREB Dephosphorylation. J Mol Neurosci 62(2):154-162. https://doi.org/10.1007/s12031-017-0919-8

35. Cai Y, Yu SS, He Y, Bi XY, Gao S, Yan TD, Zheng GD, Chen TT, Ye JT, Liu PQ (2021) EGCG inhibits pressure overload-induced cardiac hypertrophy via the PSMB5/Nmnat2/SIRT6-dependent signalling pathways. Acta Physiol (Oxf) 231(4):e13602. https://doi.org/10.1111/apha.13602

36. Skouta R, Dixon SJ, Wang J, Dunn DE, Orman M, Shimada K, Rosenberg PA, Lo DC, Weinberg JM, Linkermann A, Stockwell BR (2014) Ferrostatins inhibit oxidative lipid damage and cell death in diverse disease models. J Am Chem Soc 136(12):4551-4556. https://doi.org/10.1021/ja411006a

37. Choi WS, Palmiter RD, Xia Z (2011) Loss of mitochondrial complex I activity potentiates dopamine neuron death induced by microtubule dysfunction in a Parkinson's disease model. J Cell Biol 192(5):873-882. https://doi.org/10.1083/jcb.201009132

38. Mandelkow E-M, Mandelkow E (1998) Tau in Alzheimer's disease. Trends Cell Biol 8(11):425-427. https://doi.org/https://doi.org/10.1016/S0962-8924(98)01368-3 
39. Ding H, Matthews TA, Johnson GV (2006) Site-specific phosphorylation and caspase cleavage differentially impact tau-microtubule interactions and tau aggregation. J Biol Chem 281(28):1910719114. https://doi.org/10.1074/jbc.M511697200

40. Neddens J, Temmel M, Flunkert S, Kerschbaumer B, Hoeller C, Loeffler T, Niederkofler V, Daum G, Attems J, Hutter-Paier B (2018) Phosphorylation of different tau sites during progression of Alzheimer's disease. Acta Neuropathol Commun 6(1):52. https://doi.org/10.1186/s40478-018-05576

41. Ly PT, Wu Y, Zou H, Wang R, Zhou W, Kinoshita A, Zhang M, Yang Y, Cai F, Woodgett J, Song W (2013) Inhibition of GSK3ß-mediated BACE1 expression reduces Alzheimer-associated phenotypes. J Clin Invest 123(1):224-235. https://doi.org/10.1172/jci64516

42. Jackson GR, Wiedau-Pazos M, Sang TK, Wagle N, Brown CA, Massachi S, Geschwind DH (2002) Human wild-type tau interacts with wingless pathway components and produces neurofibrillary pathology in Drosophila. Neuron 34(4):509-519. https://doi.org/10.1016/s0896-6273(02)00706-7

43. Hernández F, Gómez de Barreda E, Fuster-Matanzo A, Lucas JJ, Avila J (2010) GSK3: a possible link between beta amyloid peptide and tau protein. Exp Neurol 223(2):322-325.

https://doi.org/10.1016/j.expneurol.2009.09.011

44. Ferrer I, Gomez-Isla T, Puig B, Freixes M, Ribé E, Dalfó E, Avila J (2005) Current advances on different kinases involved in tau phosphorylation, and implications in Alzheimer's disease and tauopathies. Curr Alzheimer Res 2(1):3-18. https://doi.org/10.2174/1567205052772713

45. Dikic I (2017) Proteasomal and Autophagic Degradation Systems. Annu Rev Biochem 86:193-224. https://doi.org/10.1146/annurev-biochem-061516-044908

46. Wang P, Joberty G, Buist A, Vanoosthuyse A, Stancu IC, Vasconcelos B, Pierrot N, Faelth-Savitski M, Kienlen-Campard P, Octave JN, Bantscheff M, Drewes G, Moechars D, Dewachter I (2017) Tau interactome mapping based identification of Otub1 as Tau deubiquitinase involved in accumulation of pathological Tau forms in vitro and in vivo. Acta Neuropathol 133(5):731-749. https://doi.org/10.1007/s00401-016-1663-9

47. Vaz-Silva J, Gomes P, Jin Q, Zhu M, Zhuravleva V, Quintremil S, Meira T, Silva J, Dioli C, Soares-Cunha C, Daskalakis NP, Sousa N, Sotiropoulos I, Waites CL (2018) Endolysosomal degradation of Tau and its role in glucocorticoid-driven hippocampal malfunction. Embo j 37(20). https://doi.org/10.15252/embj.201899084

48. Jung T, Catalgol B, Grune T (2009) The proteasomal system. Mol Aspects Med 30(4):191-296. https://doi.org/10.1016/j.mam.2009.04.001

49. Spotorno N, Acosta-Cabronero J, Stomrud E, Lampinen B, Strandberg OT, van Westen D, Hansson O (2020) Relationship between cortical iron and tau aggregation in Alzheimer's disease. Brain 143(5):1341-1349. https://doi.org/10.1093/brain/awaa089

50. Sayre LM, Perry G, Harris PL, Liu Y, Schubert KA, Smith MA (2000) In situ oxidative catalysis by neurofibrillary tangles and senile plaques in Alzheimer's disease: a central role for bound transition metals. J Neurochem 74(1):270-279. https://doi.org/10.1046/j.1471-4159.2000.0740270.x 
51. Rottkamp CA, Raina AK, Zhu X, Gaier E, Bush Al, Atwood CS, Chevion M, Perry G, Smith MA (2001) Redox-active iron mediates amyloid-beta toxicity. Free Radic Biol Med 30(4):447-450. https://doi.org/10.1016/s0891-5849(00)00494-9

52. Kim AC, Lim S, Kim YK (2018) Metal Ion Effects on A $\beta$ and Tau Aggregation. Int J Mol Sci 19(1). doi:10.3390/ijms19010128

53. Lee S, Viqar F, Zimmerman ME, Narkhede A, Tosto G, Benzinger TL, Marcus DS, Fagan AM, Goate A, Fox NC, Cairns NJ, Holtzman DM, Buckles V, Ghetti B, McDade E, Martins RN, Saykin AJ, Masters CL, Ringman JM, Ryan NS, Förster S, Laske C, Schofield PR, Sperling RA, Salloway S, Correia S, Jack C Jr, Weiner M, Bateman RJ, Morris JC, Mayeux R, Brickman AM (2016) White matter hyperintensities are a core feature of Alzheimer's disease: Evidence from the dominantly inherited Alzheimer network. Ann Neurol 79(6):929-939. https://doi.org/10.1002/ana.24647

54. Dziewulska D, Rafałowska J (2005) Proteinaceous intracellular inclusions in neurodegenerative disorders. Folia Neuropathol 43(2):51-63

55. Yang WS, Stockwell BR (2008) Synthetic lethal screening identifies compounds activating irondependent, nonapoptotic cell death in oncogenic-RAS-harboring cancer cells. Chem Biol 15(3):234245. https://doi.org/10.1016/j.chembiol.2008.02.010

56. Friedmann Angeli JP, Schneider M, Proneth B, Tyurina YY, Tyurin VA, Hammond VJ, Herbach N, Aichler M, Walch A, Eggenhofer E, Basavarajappa D, Rådmark O, Kobayashi S, Seibt T, Beck H, Neff F, Esposito I, Wanke R, Förster H, Yefremova O, Heinrichmeyer M, Bornkamm GW, Geissler EK, Thomas SB, Stockwell BR, O'Donnell VB, Kagan VE, Schick JA, Conrad M (2014) Inactivation of the ferroptosis regulator Gpx4 triggers acute renal failure in mice. Nat Cell Biol 16(12):1180-1191. https://doi.org/10.1038/ncb3064

57. Martin L, Latypova X, Terro F (2011) Post-translational modifications of tau protein: implications for Alzheimer's disease. Neurochem Int 58(4):458-471. https://doi.org/10.1016/j.neuint.2010.12.023

58. Lu PJ, Wulf G, Zhou XZ, Davies P, Lu KP (1999) The prolyl isomerase Pin1 restores the function of Alzheimer-associated phosphorylated tau protein. Nature 399(6738):784-788. https://doi.org/10.1038/21650

59. Bramblett GT, Goedert M, Jakes R, Merrick SE, Trojanowski JQ, Lee VM (1993) Abnormal tau phosphorylation at Ser396 in Alzheimer's disease recapitulates development and contributes to reduced microtubule binding. Neuron 10(6):1089-1099. https://doi.org/10.1016/08966273(93)90057-x

60. Martin L, Latypova X, Wilson CM, Magnaudeix A, Perrin ML, Yardin C, Terro F (2013) Tau protein kinases: involvement in Alzheimer's disease. Ageing Res Rev 12(1):289-309. https://doi.org/10.1016/j.arr.2012.06.003

61. Pérez M, Hernández F, Lim F, Díaz-Nido J, Avila J (2003) Chronic lithium treatment decreases mutant tau protein aggregation in a transgenic mouse model. J Alzheimers Dis 5(4):301-308. https://doi.org/10.3233/jad-2003-5405 
62. Uemura K, Kuzuya A, Shimozono Y, Aoyagi N, Ando K, Shimohama S, Kinoshita A (2007) GSK3beta activity modifies the localization and function of presenilin 1. J Biol Chem 282(21):15823-15832. https://doi.org/10.1074/jbc.M610708200

63. Giese KP (2009) GSK-3: a key player in neurodegeneration and memory. IUBMB Life 61(5):516-521. https://doi.org/10.1002/iub.187

64. Nedelsky NB, Todd PK, Taylor JP (2008) Autophagy and the ubiquitin-proteasome system: collaborators in neuroprotection. Biochim Biophys Acta 1782(12):691-699.

https://doi.org/10.1016/j.bbadis.2008.10.002

65. Ciechanover A, Kwon YT (2017) Protein Quality Control by Molecular Chaperones in Neurodegeneration. Front Neurosci 11:185. https://doi.org/10.3389/fnins.2017.00185

66. Deng Z, Purtell K, Lachance V, Wold MS, Chen S, Yue Z (2017) Autophagy Receptors and Neurodegenerative Diseases. Trends Cell Biol 27(7):491-504.

https://doi.org/10.1016/j.tcb.2017.01.001

67. Clague MJ, Urbé S (2010) Ubiquitin: same molecule, different degradation pathways. Cell 143(5):682-685. https://doi.org/10.1016/j.cell.2010.11.012

68. Glickman $\mathrm{MH}$, Ciechanover A (2002) The ubiquitin-proteasome proteolytic pathway: destruction for the sake of construction. Physiol Rev 82(2):373-428. https://doi.org/10.1152/physrev.00027.2001

69. Xie M, Shi R, Pan Y, Zeng T, Chen Q, Wang S, Liao X (2014) Proteasome inhibition-induced downregulation of Akt/GSK-3 $\beta$ pathway contributes to abnormality of tau in hippocampal slice. Mol Neurobiol 50(3):888-895. https://doi.org/10.1007/s12035-014-8702-0

70. Galves M, Rathi R, Prag G, Ashkenazi A (2019) Ubiquitin Signaling and Degradation of AggregateProne Proteins. Trends Biochem Sci 44(10):872-884. https://doi.org/10.1016/j.tibs.2019.04.007

71. Thibaudeau TA, Anderson RT, Smith DM (2018) A common mechanism of proteasome impairment by neurodegenerative disease-associated oligomers. Nat Commun 9(1):1097. https://doi.org/10.1038/s41467-018-03509-0

72. Berger Z, Ravikumar B, Menzies FM, Oroz LG, Underwood BR, Pangalos MN, Schmitt I, Wullner U, Evert BO, O'Kane CJ, Rubinsztein DC (2006) Rapamycin alleviates toxicity of different aggregateprone proteins. Hum Mol Genet 15(3):433-442. https://doi.org/10.1093/hmg/ddi458

73. Ravikumar B, Vacher C, Berger Z, Davies JE, Luo S, Oroz LG, Scaravilli F, Easton DF, Duden R, O'Kane CJ, Rubinsztein DC (2004) Inhibition of mTOR induces autophagy and reduces toxicity of polyglutamine expansions in fly and mouse models of Huntington disease. Nat Genet 36(6):585595. https://doi.org/10.1038/ng1362

74. Wang Y, Krüger U, Mandelkow E, Mandelkow EM (2010) Generation of tau aggregates and clearance by autophagy in an inducible cell model of tauopathy. Neurodegener Dis 7(1-3):103-107. https://doi.org/10.1159/000285516

75. Lin WM, Li ZG (2015) Blockage of cisplatin-induced autophagy sensitizes cervical cancer cells to cisplatin. Genet Mol Res 14(4):16905-16912. https://doi.org/10.4238/2015.December.14.18 
76. Park E, Chung SW (2019) ROS-mediated autophagy increases intracellular iron levels and ferroptosis by ferritin and transferrin receptor regulation. Cell Death Dis 10(11):822. https://doi.org/10.1038/s41419-019-2064-5

\section{Figures}
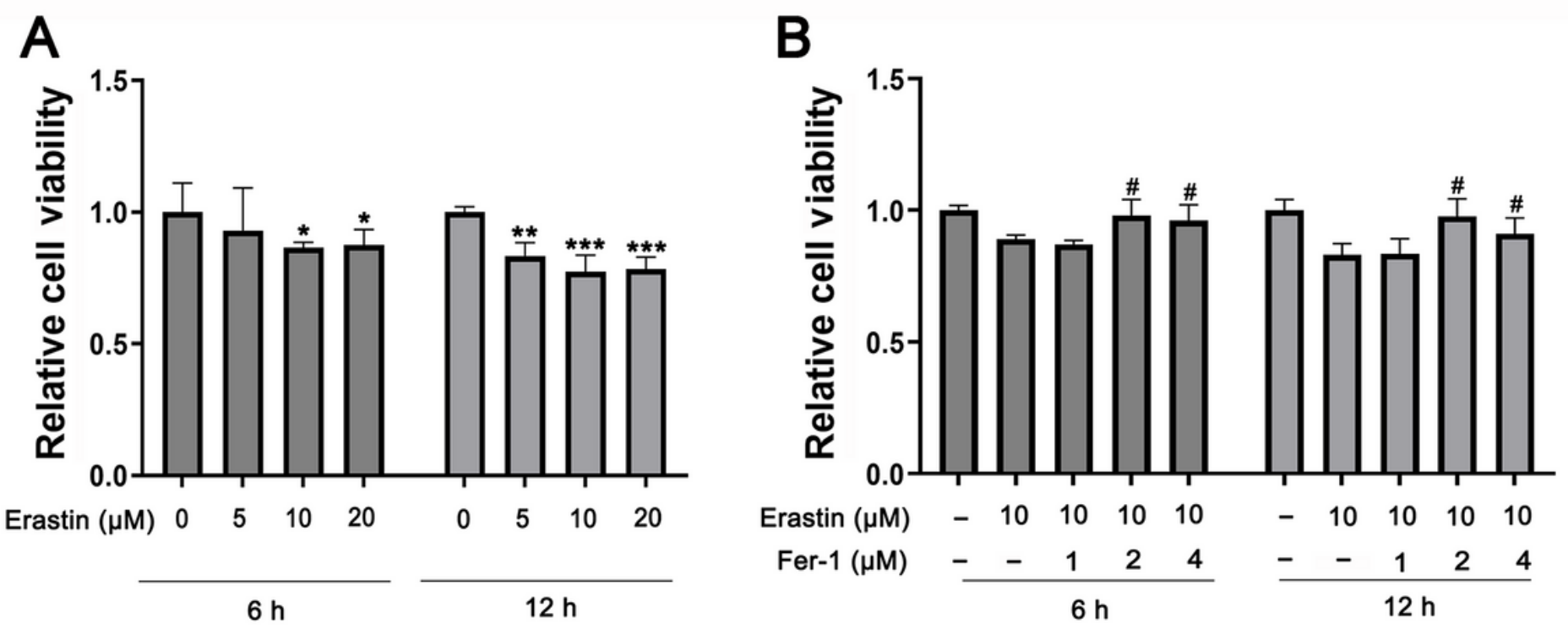

Figure 1

Effects of erastin and ferrostatin-1 on N2a cell viability. A, the relative viability of N2a cells treated with 5,10 and $20 \mu \mathrm{M}$ erastin for 6 and $12 \mathrm{hr}$ respectively. B, the relative viability of N2a cells co-treated with 10 $\mu \mathrm{M}$ erastin and 1, 2 and $4 \mu \mathrm{M}$ ferrostatin-1 (Fer-1) for 6 and $12 \mathrm{hr}$ respectively. Data are represented as means $\pm S D(n=3) .{ }^{*} p<0.05,{ }^{*} p<0.01,{ }^{* \star *} p<0.001$ as compared with the control group; $\# p<0.05$, as compared with erastin treatment group. 


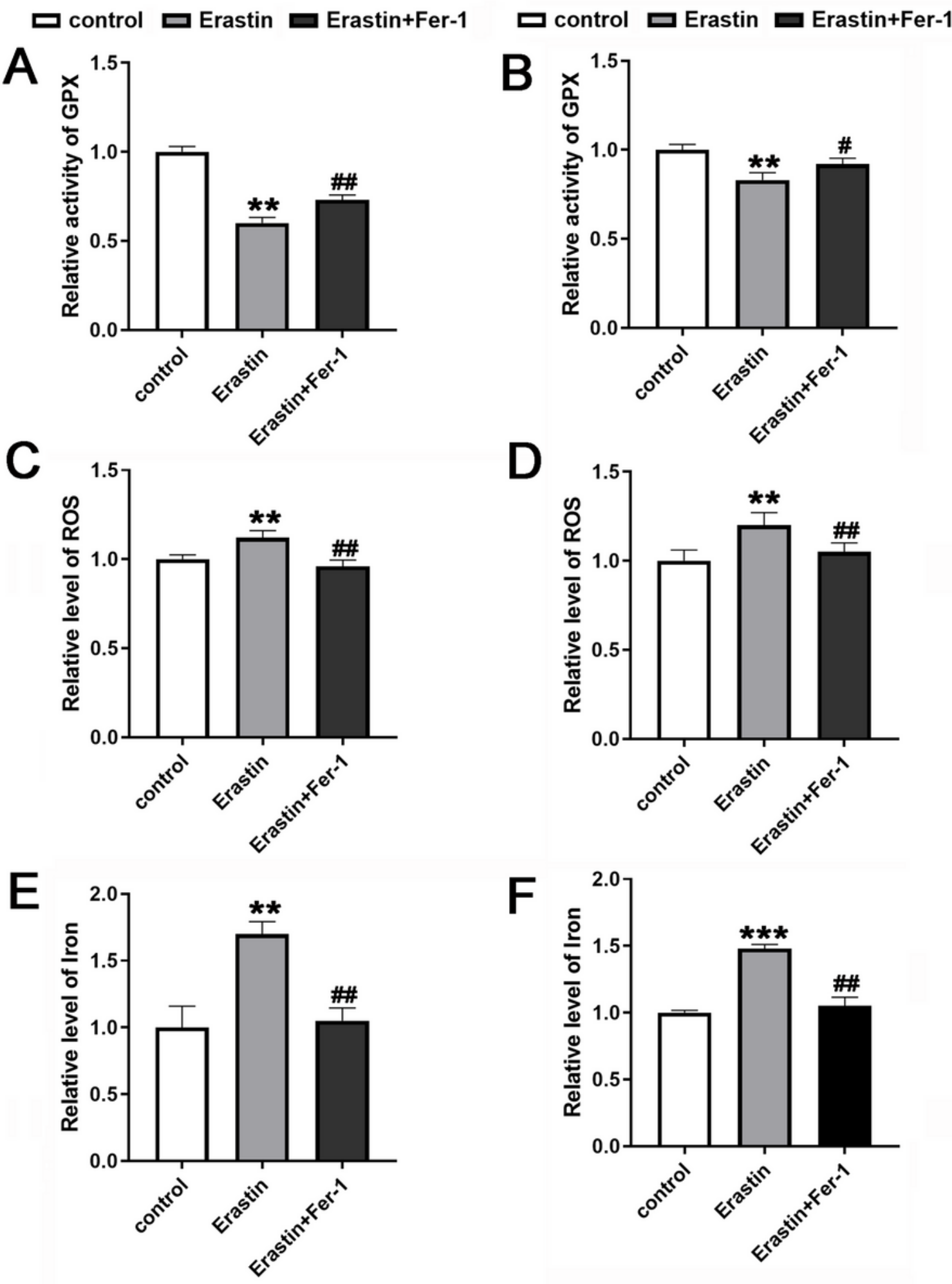

Figure 2

Erastin treatment induces GPX activity, ROS and iron levels imbalance in N2a cells. A-B, changes of intracellular GPX activity in N2a cells treated with $10 \mu \mathrm{M}$ erastin or $10 \mu \mathrm{M}$ erastin plus $2 \mu \mathrm{M}$ ferrostatin-1 for 6 and $12 \mathrm{hr}$ respectively. C-D, changes of intracellular ROS content in N2a cells treated with $10 \mu \mathrm{M}$ erastin or $10 \mu \mathrm{M}$ erastin plus $2 \mu \mathrm{M}$ ferrostatin- 1 for 6 and $12 \mathrm{hr}$, respectively. E-F, Changes of intracellular iron levels in N2a cells treated with $10 \mu \mathrm{M}$ erastin or $10 \mu \mathrm{M}$ erastin plus $2 \mu \mathrm{M}$ ferrostatin- 1 for 6 and $12 \mathrm{hr}$, 
respectively. ${ }^{* \star} p<0.01$, as compared with the control group; $\# p<0.05, \# \# p<0.01$, compared with the erastin treatment group.
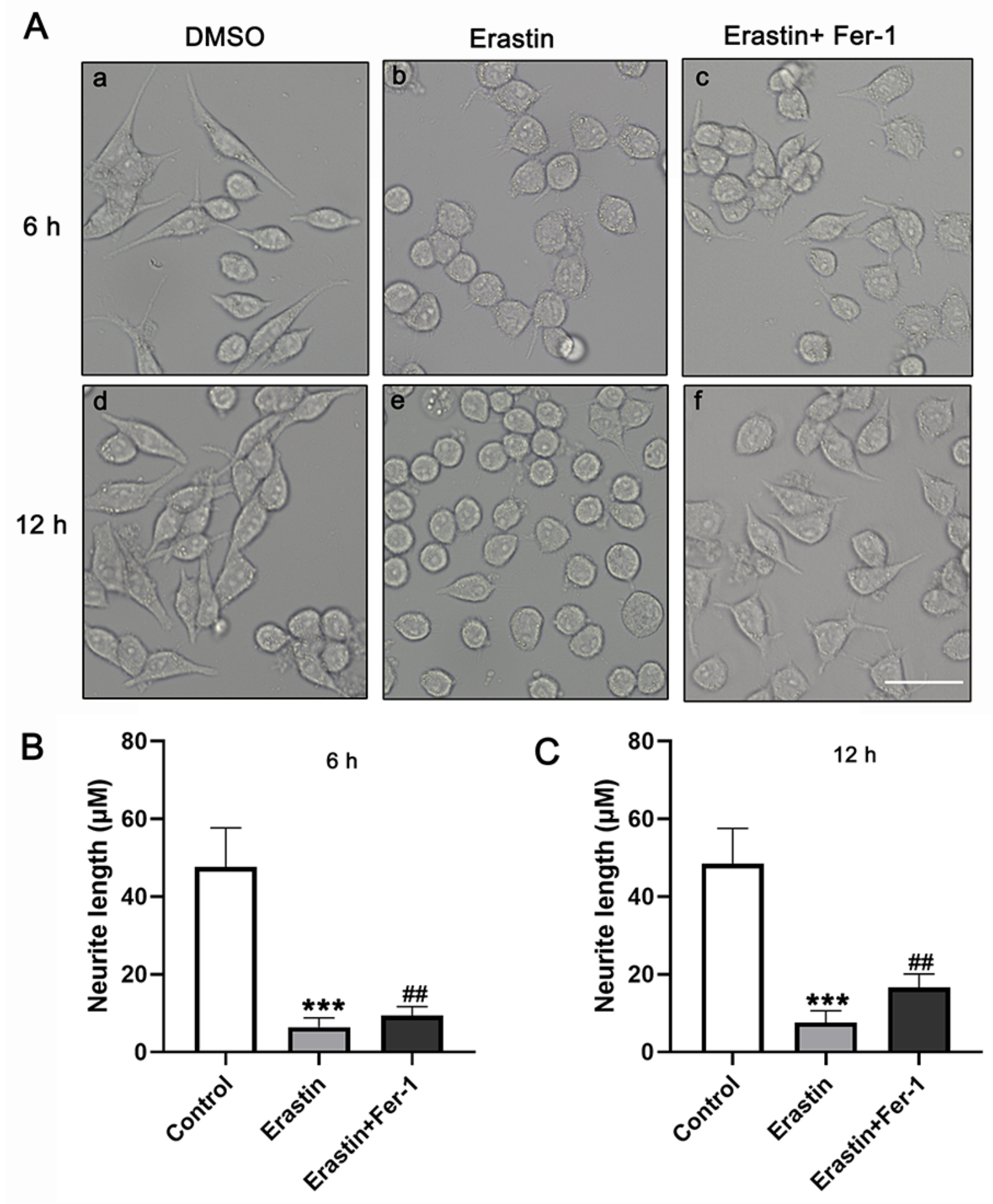

Figure 3

The effects of erastin and ferrostatin-1 on the morphology of N2a cells. A, the morphology of N2a cells treated with DMSO, $10 \mu \mathrm{M}$ erastin, and $10 \mu \mathrm{M}$ erastin plus $2 \mu \mathrm{M}$ ferrostatin-1 for $6 \mathrm{hr}(\mathrm{a}-\mathrm{c})$ and $12 \mathrm{hr}(\mathrm{d}-\mathrm{f})$, respectively. B, the quantification of neurite length of $6 \mathrm{hr}$ group and C, the quantification of neurite length 
of $12 \mathrm{hr}$ group. ${ }^{\star \star \star} p<0.001$, as compared with the control group; $\# \# p<0.01$, as compared with the erastin treatment group. Scale bar $=50 \mu \mathrm{m}$.

层

Figure 4

Erastin induced tau aggregation in N2a cells. The staining of tau protein (red) and vimentin (green) in N2a cells treated with erastin $(10 \mu \mathrm{M})$ or erastin plus $2 \mu \mathrm{M}$ ferrostatin- 1 for $6 \mathrm{hr}(\mathrm{A})$ and $12 \mathrm{hr}$ (B). Red fluorescence represents tau protein labeled with tau- 5 antibody $(a, e, i)$; green fluorescence represents the vimentin $(b, f, j)$; blue fluorescence represents the nucleus of DAPI labeled cells $(c, g, k)$, arrows represent tau protein aggregates. Scale bar $=20 \mu \mathrm{m}$. 

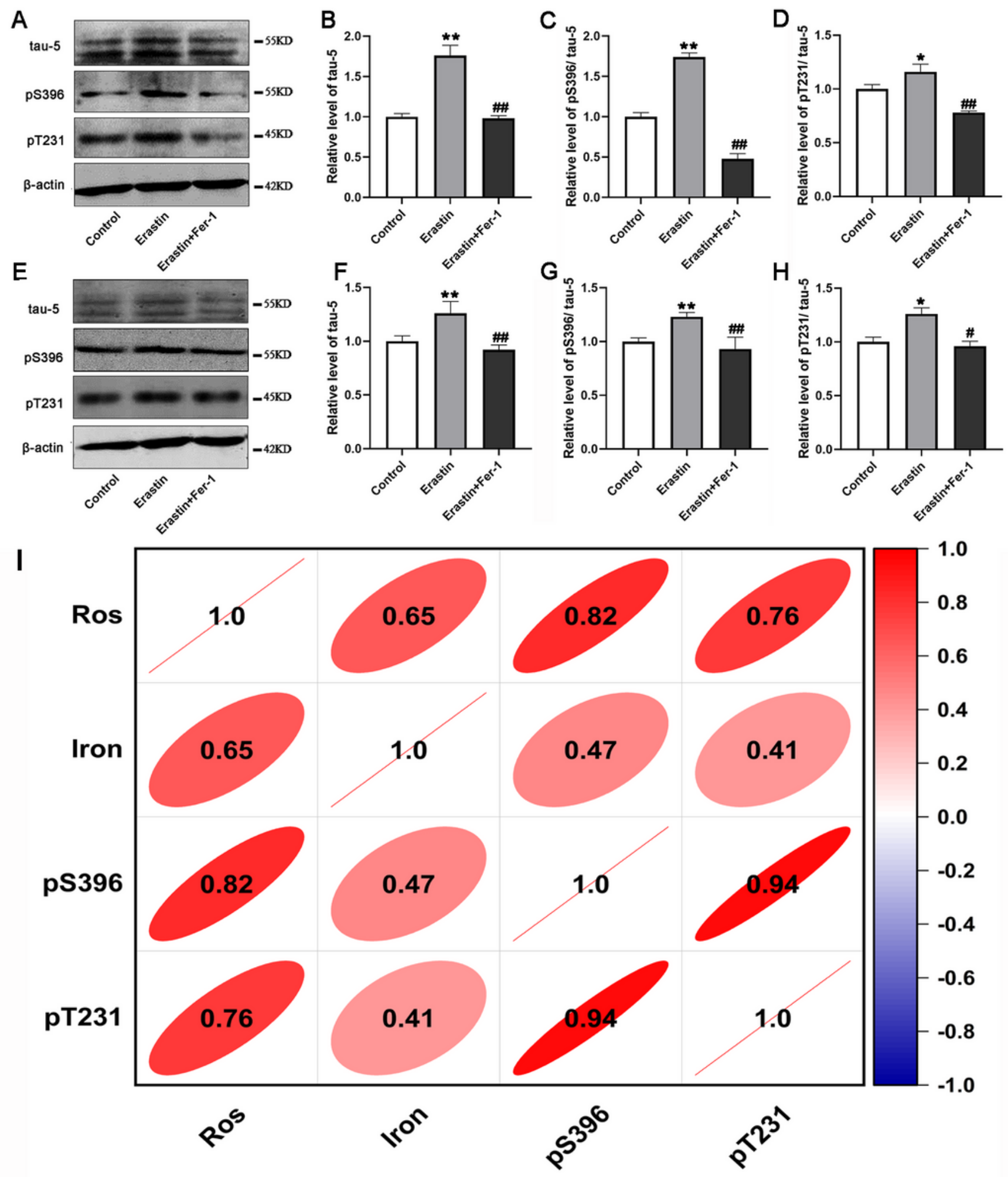

Figure 5

Erastin increased the level of total tau and phosphorylated tau in N2a cells. A and E, representative blots of total tau and phosphorylated tau-Ser396 and Thr231 after cells were treated with $10 \mu \mathrm{M}$ erastin for 6 $\mathrm{hr}(\mathrm{A})$ and $12 \mathrm{hr}(\mathrm{E})$ respectively. B-D, Quantitative analysis of the relative levels of tau-5, p-tau at Ser396, and p-tau at Thr231 after treating for $6 \mathrm{hr}$. F-H, Quantitative analysis of the relative levels of tau-5, p-tau at Ser396, and p-tau at Thr231 after treating for $12 \mathrm{hr}$. I, the correlation coefficients between ROS content, 
iron levels, and tau phosphorylation at Ser396 and Thr231 sites. Data were expressed as the means \pm SD $(n=3) .{ }^{*} p<0.05,{ }^{\star *} p<0.01$, as compared with the control group; $\# p<0.05, \# \# p<0.01$ as compared with erastin treatment group.
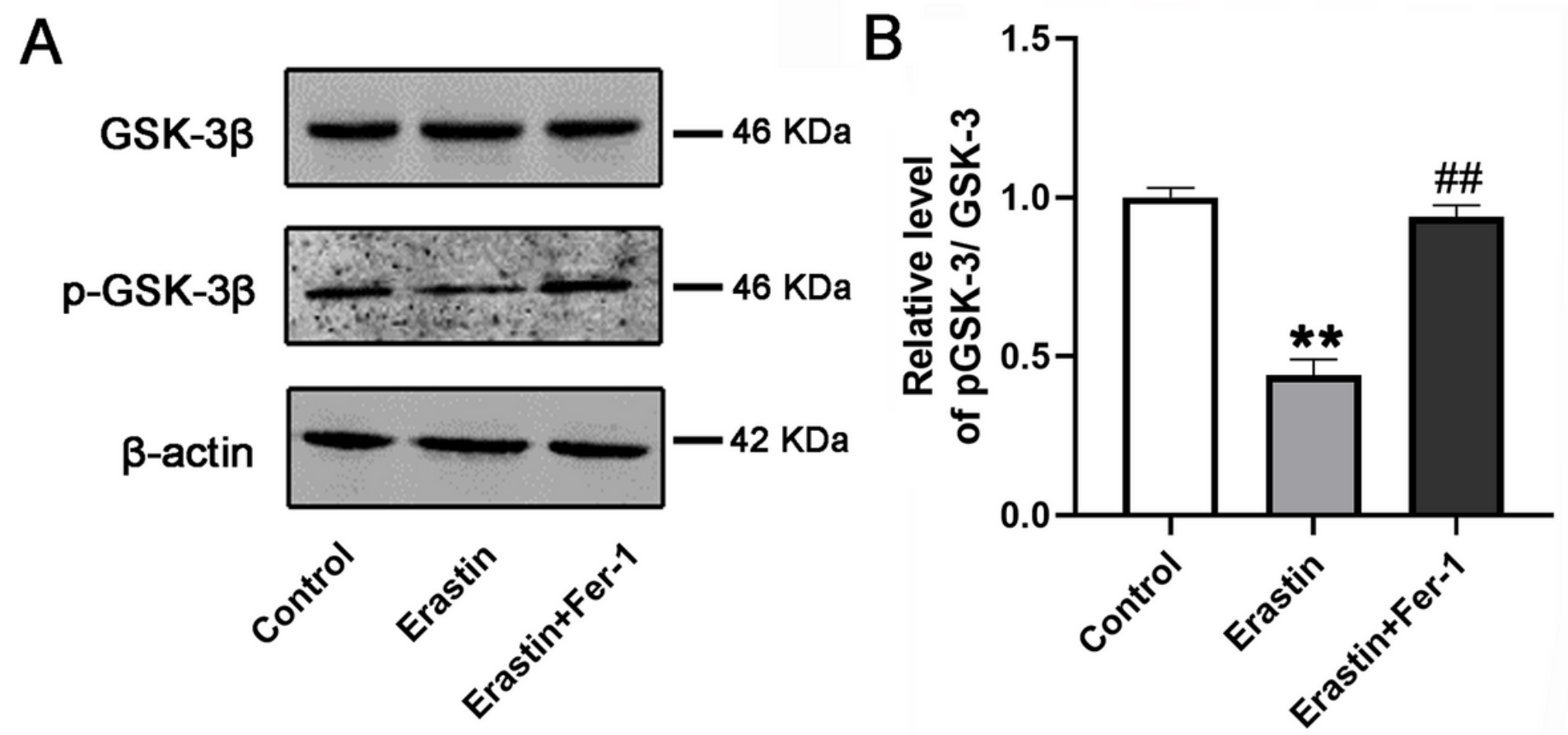

C
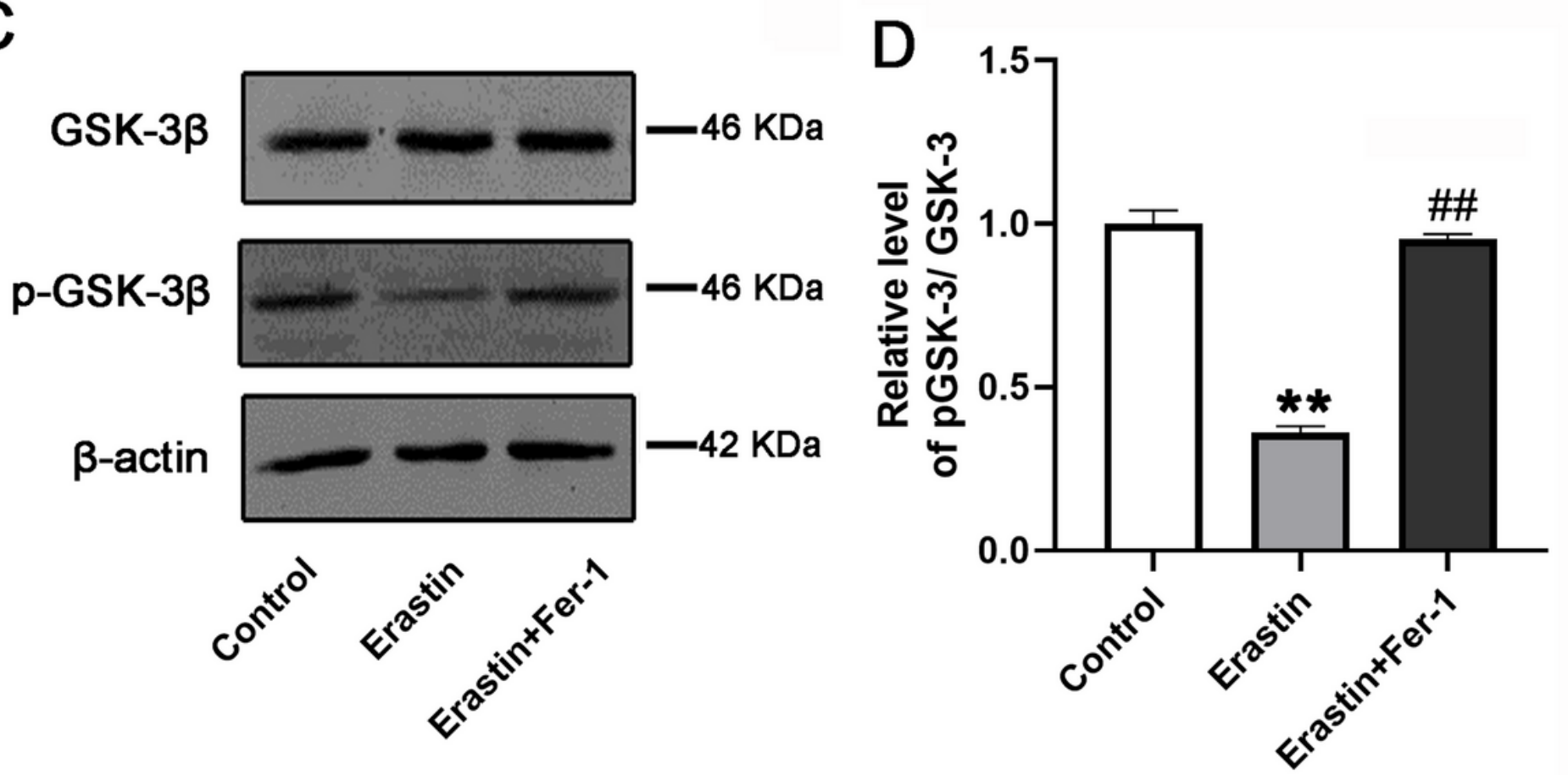

Figure 6

Erastin activated GSK-3 $\beta$ in N2a cells. The level of intracellular GSK-3 $\beta$ and Ser9-phosphorylated GSK-3 $\beta$ in N2a cells following erastin $(10 \mu \mathrm{M})$, and erastin plus ferrostatin-1 $(2 \mu \mathrm{M})$ treatment for $6 \mathrm{hr}(\mathrm{A}, \mathrm{B})$ and $12 \mathrm{hr}(\mathrm{C}, \mathrm{D})$, respectively. The protein levels were expressed as fold changes over control cells and are 
represented as mean $\pm S D$. ${ }^{*} p<<0.01$, as compared with the control group; $\# \# p<0.01$ as compared with the erastin treatment group.

A

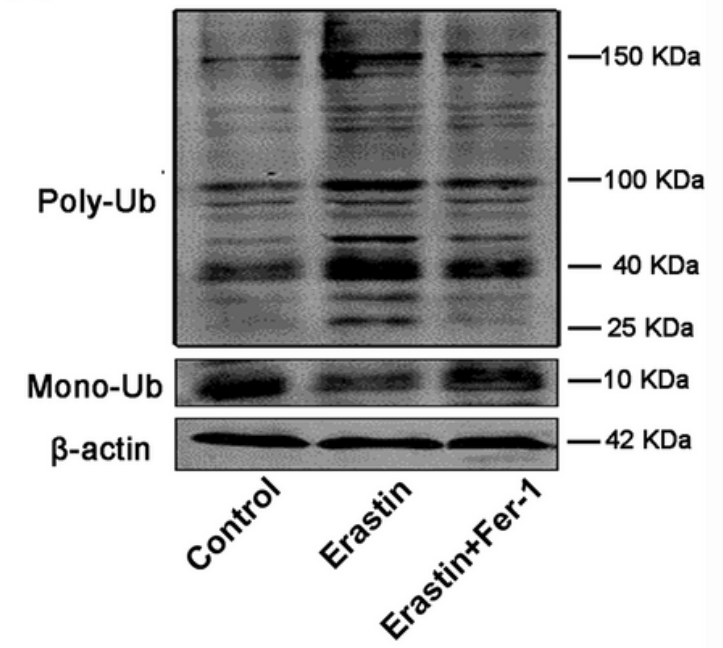

D

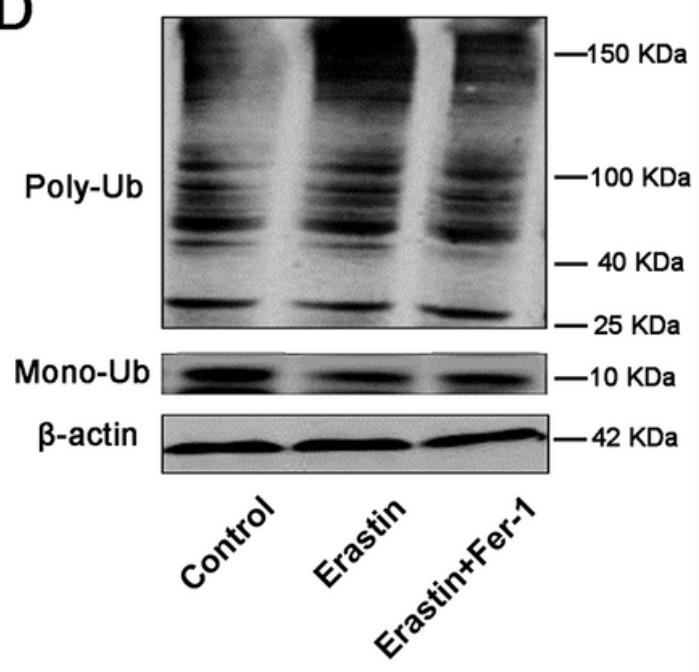

B

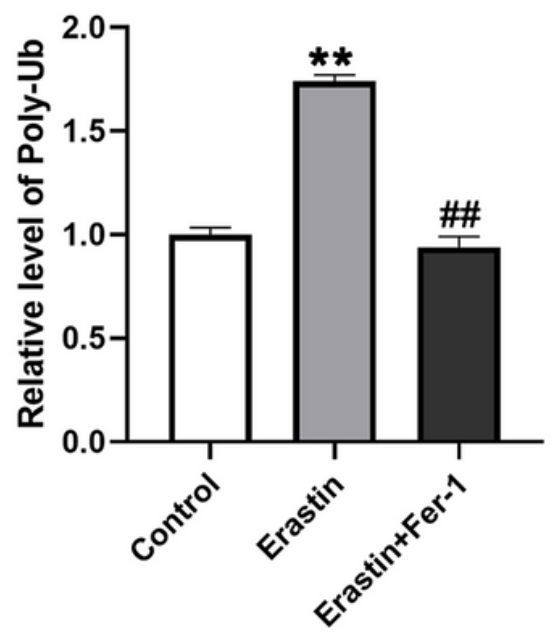

E

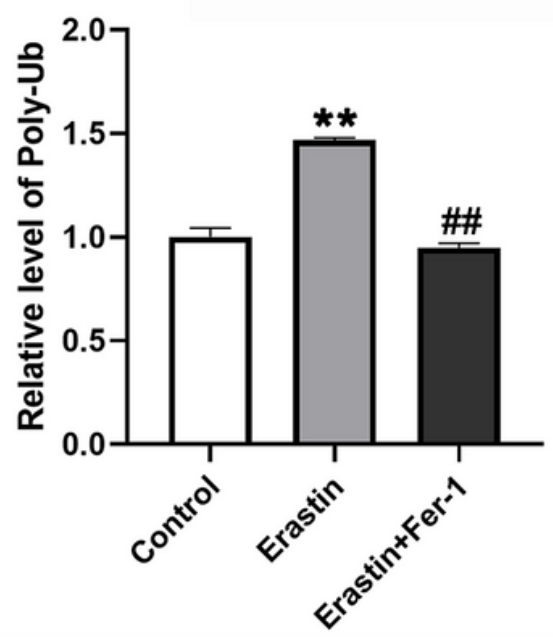

C

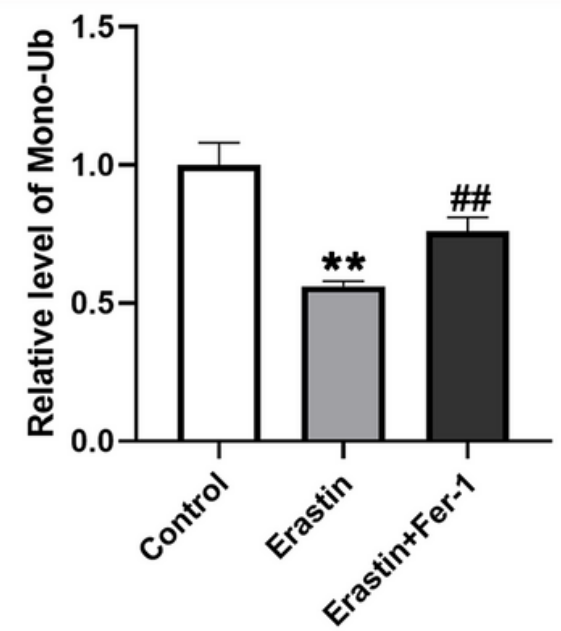

F

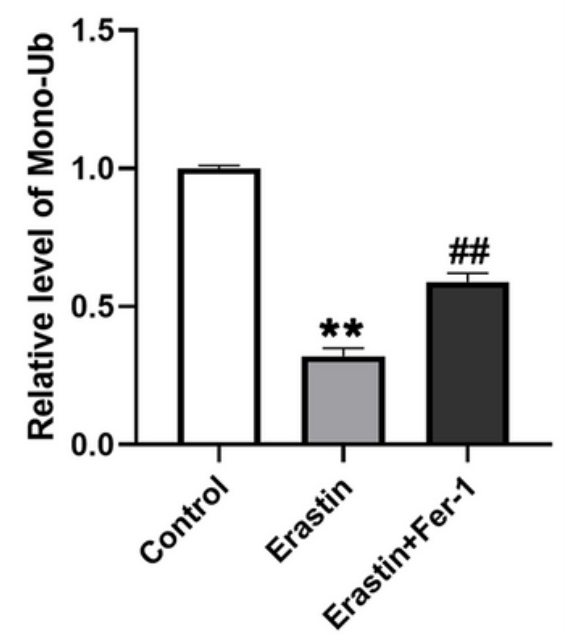

Figure 7

The effects of erastin on ubiquitin levels in N2a cells. The intracellular Poly-Ub and Mono-Ub content changes were detected by Western blot after erastin, or erastin plus ferrostatin- 1 treatment for $6 \mathrm{hr}$ and 12 $\mathrm{hr}$, respectively. A, B, and C, the relative levels of Poly-Ub and Mono-Ub after $6 \mathrm{hr}$. D, E, and F, the relative levels of Poly-Ub and Mono-Ub after $12 \mathrm{hr}$. The values were expressed as fold changes over control and are represented as mean $\pm S D(n=3)$. ${ }^{\star \star} p<0.01$, as compared with the control group; $\# \# p<0.01$ as compared with the erastin treatment group. 
A
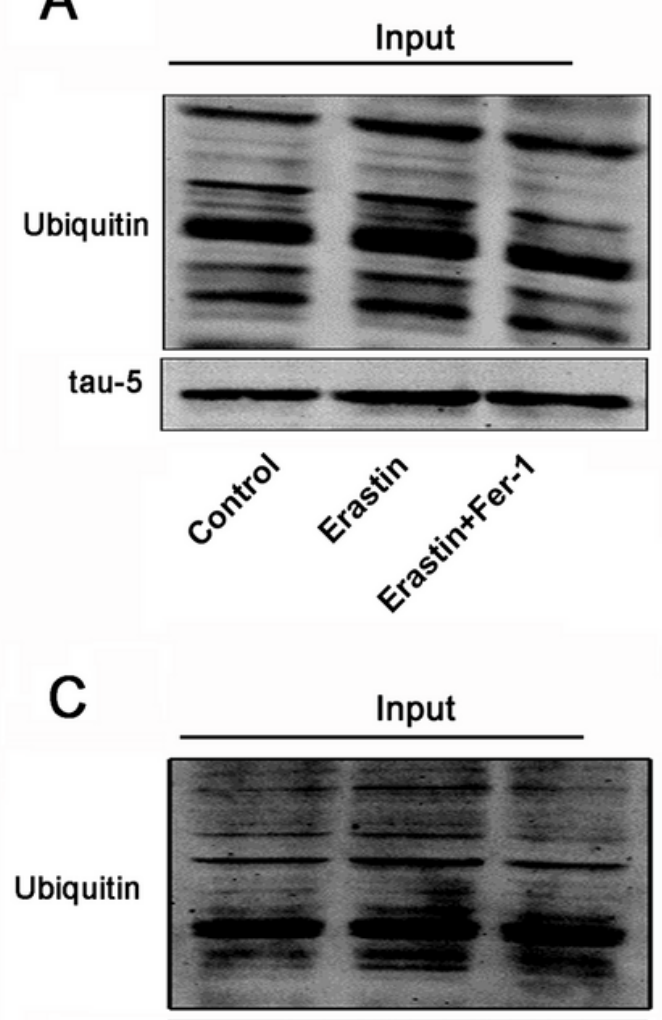

tau-5
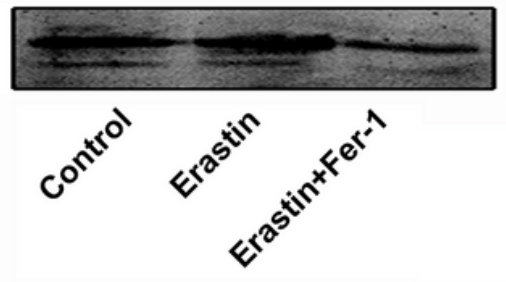
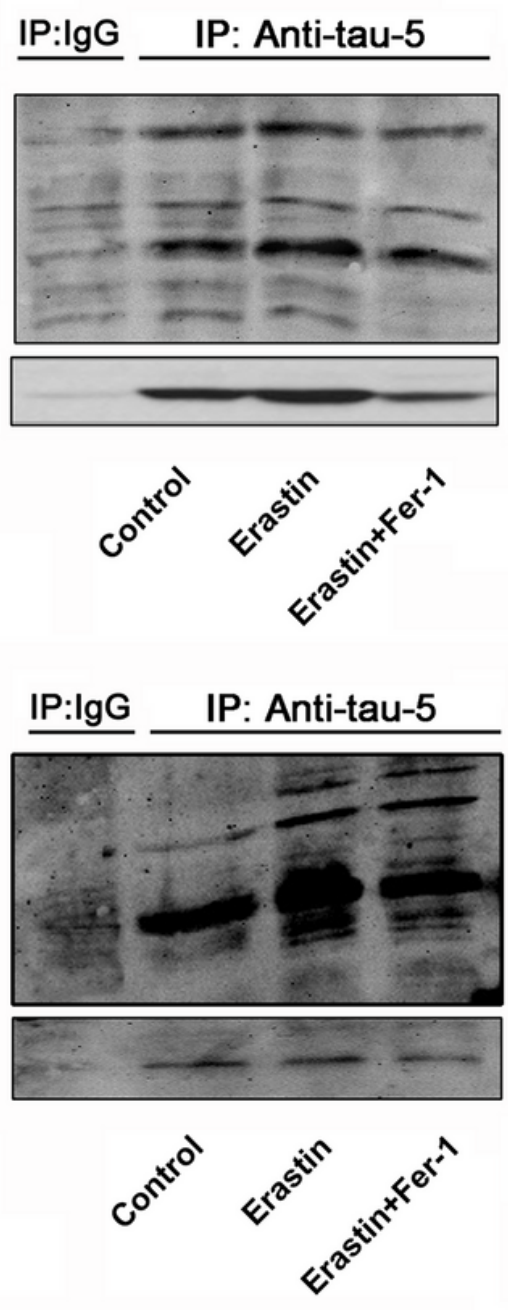

B

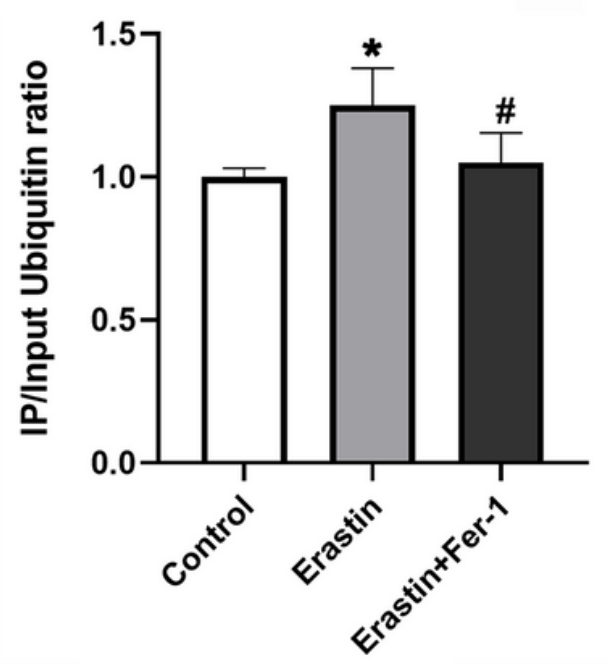

D

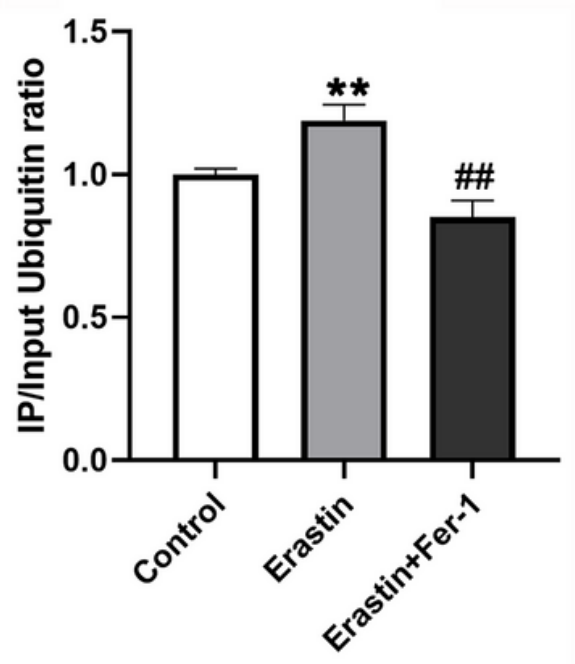

Figure 8

Erastin treatment increased ubiquitinated tau in N2a cells. Extracts from cells were immunoprecipitated with anti-lgG control and anti-total tau antibody (tau-5). The immunoprecipitation was detected with an anti-ubiquitin antibody and tau-5. A and C, the input panel shows the presence of the studied proteins prior to immunoprecipitation in the extracts. $B$ and $D$, quantification of the ratios of immunoprecipitated tau versus total input tau protein from three independent experiments. Values were normalized to those of the control group and represented the mean $\pm S D(n=3)$. ${ }^{*} p<0.05,{ }^{* *} p<0.01$, as compared with the control group; $\# p<0.05, \# \# p<0.01$ as compared with the erastin treatment group. 

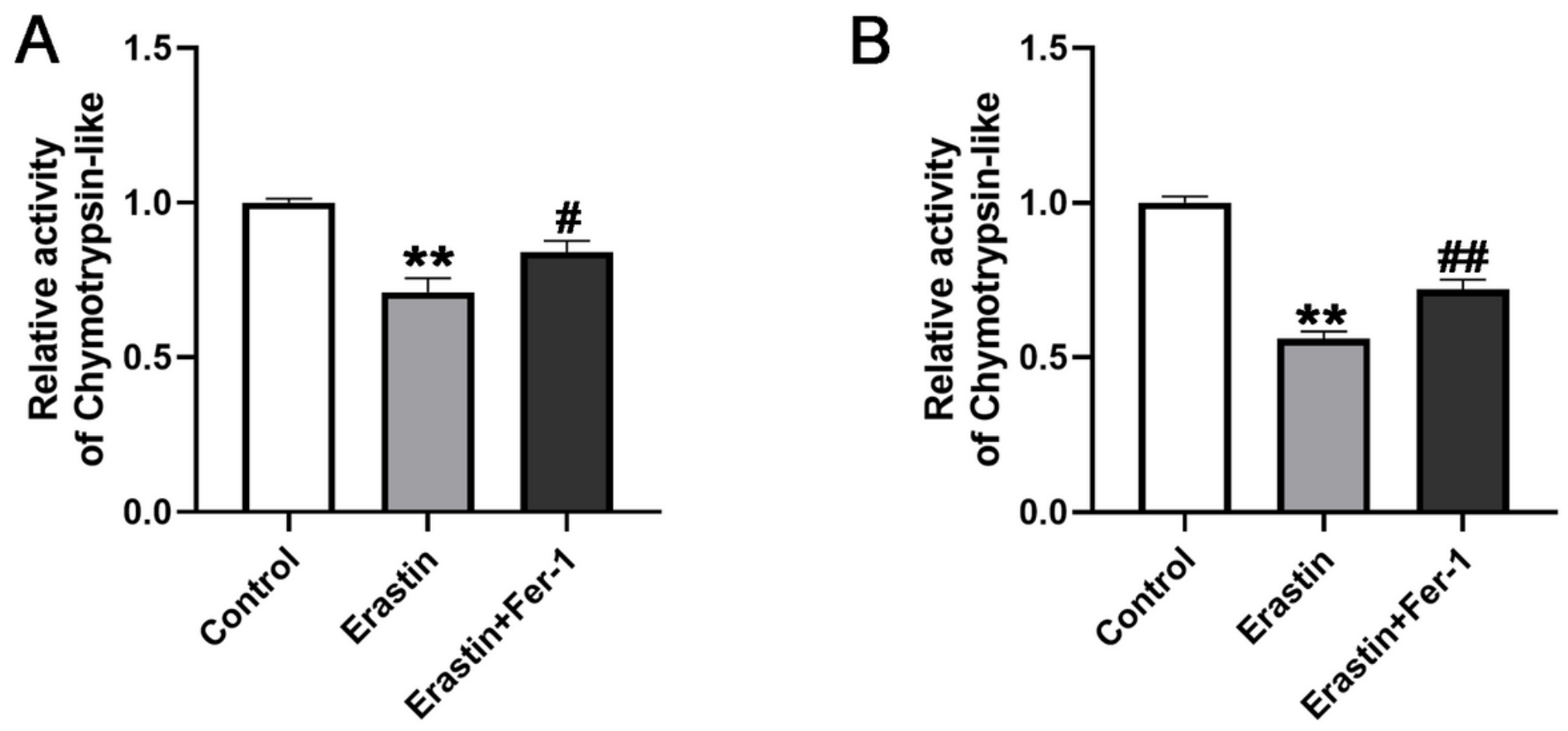

Figure 9

Erastin treatment decreased the chymotrypsin-like activity of the proteasome in N2a cells. The changes of intracellular chymotrypsin-like activity in N2a cells after $6 \mathrm{hr}(\mathrm{A})$ and $12 \mathrm{hr}(\mathrm{B})$ erastin or erastin plus ferrostatin-1 treatment, respectively. ${ }^{* \star} p<0.01$, as compared with the control group; $\# p<0.05, \# \# p<0.01$ as compared with the erastin treatment group. 
A
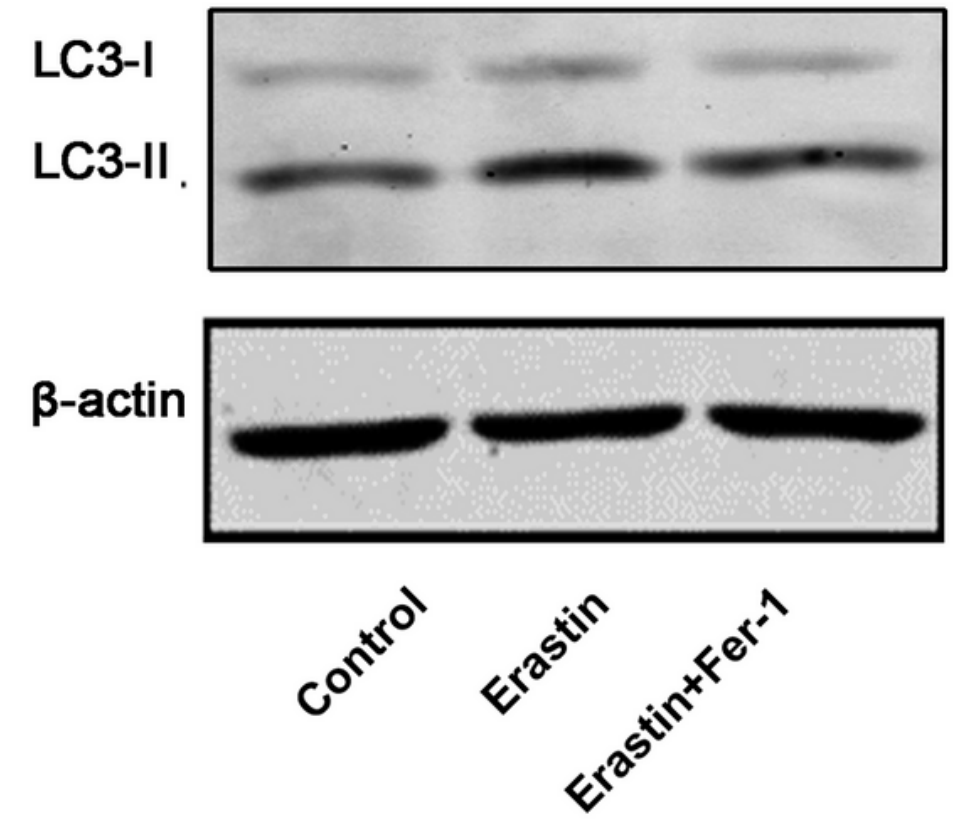

C
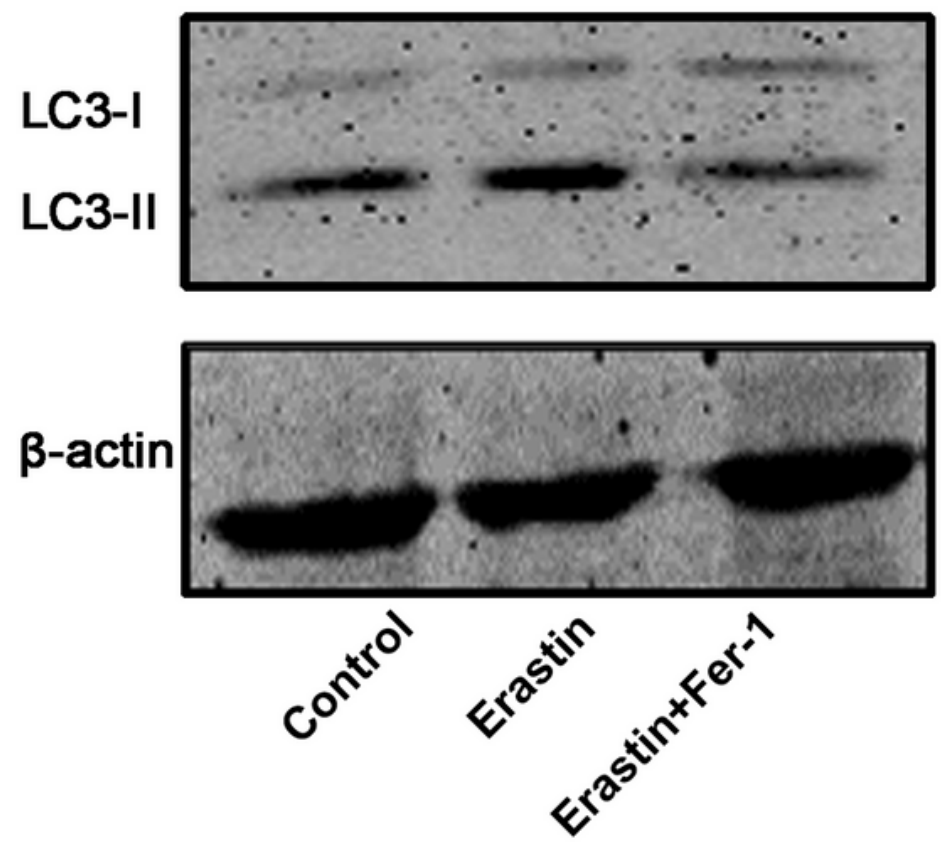

B

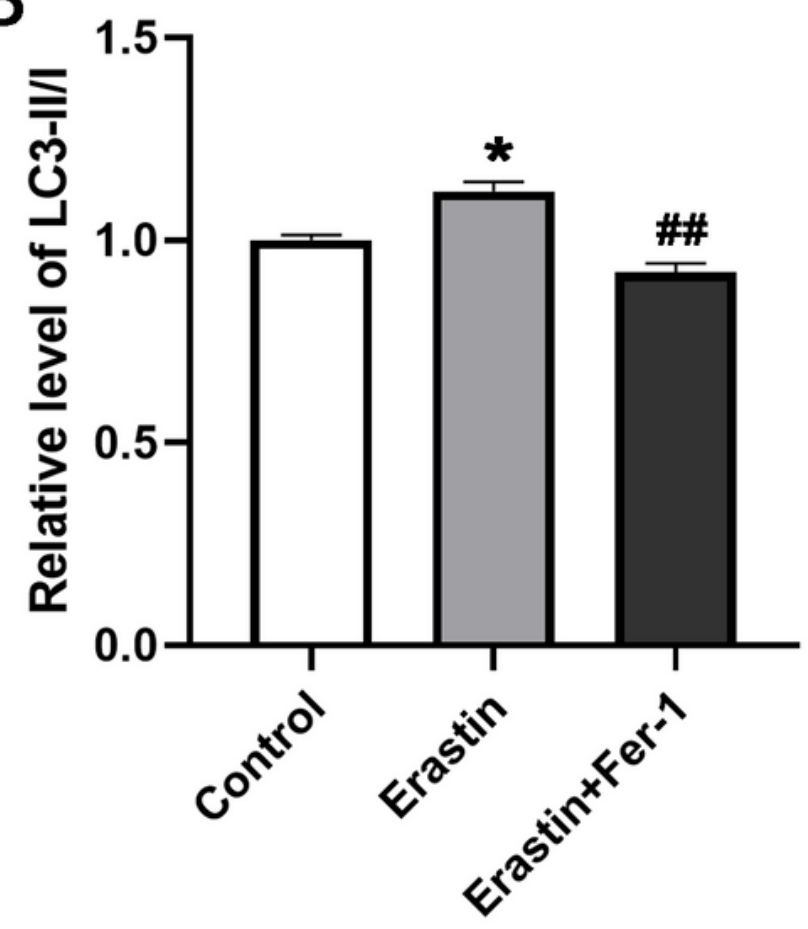

D

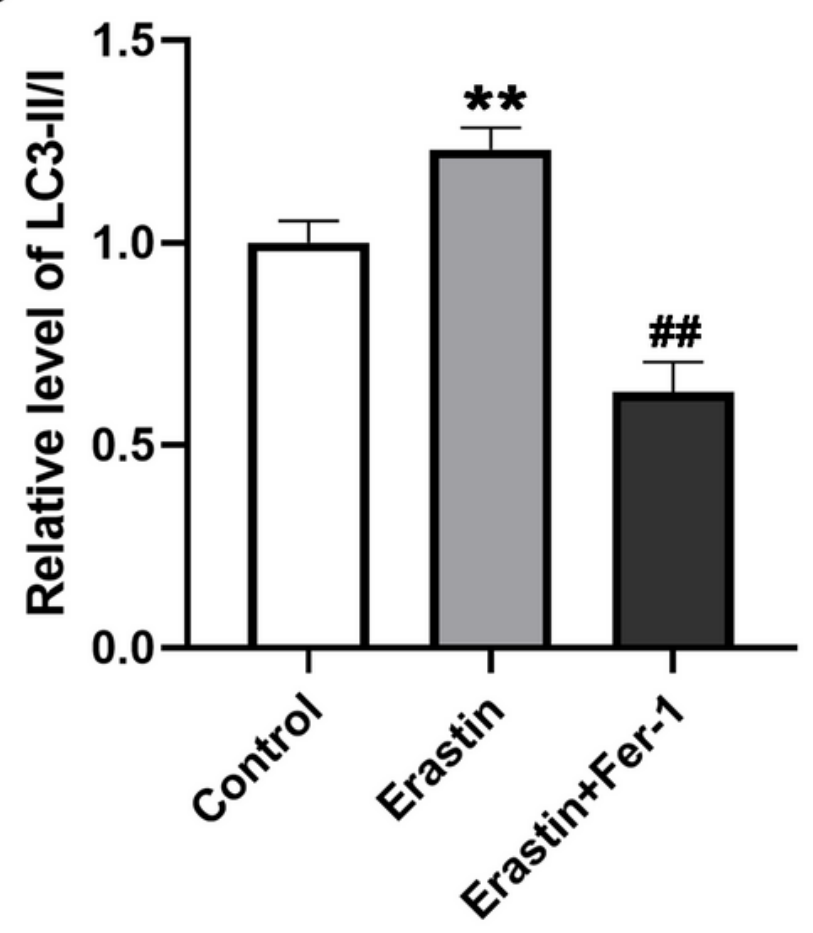

Figure 10

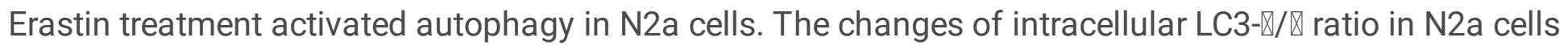
were detected by Western blot after the treatment with erastin $(10 \mu \mathrm{M})$ or erastin plus ferrostatin-1 for $6 \mathrm{hr}$ (A and B) and $12 \mathrm{hr} 6 \mathrm{hr}(C$ and $D)$. Data were expressed as the means $\pm S D(n=3)$. ${ }^{*} p<0.01$, as compared with the control group; \#\#p<0.01 as compared with the erastin treatment group. 


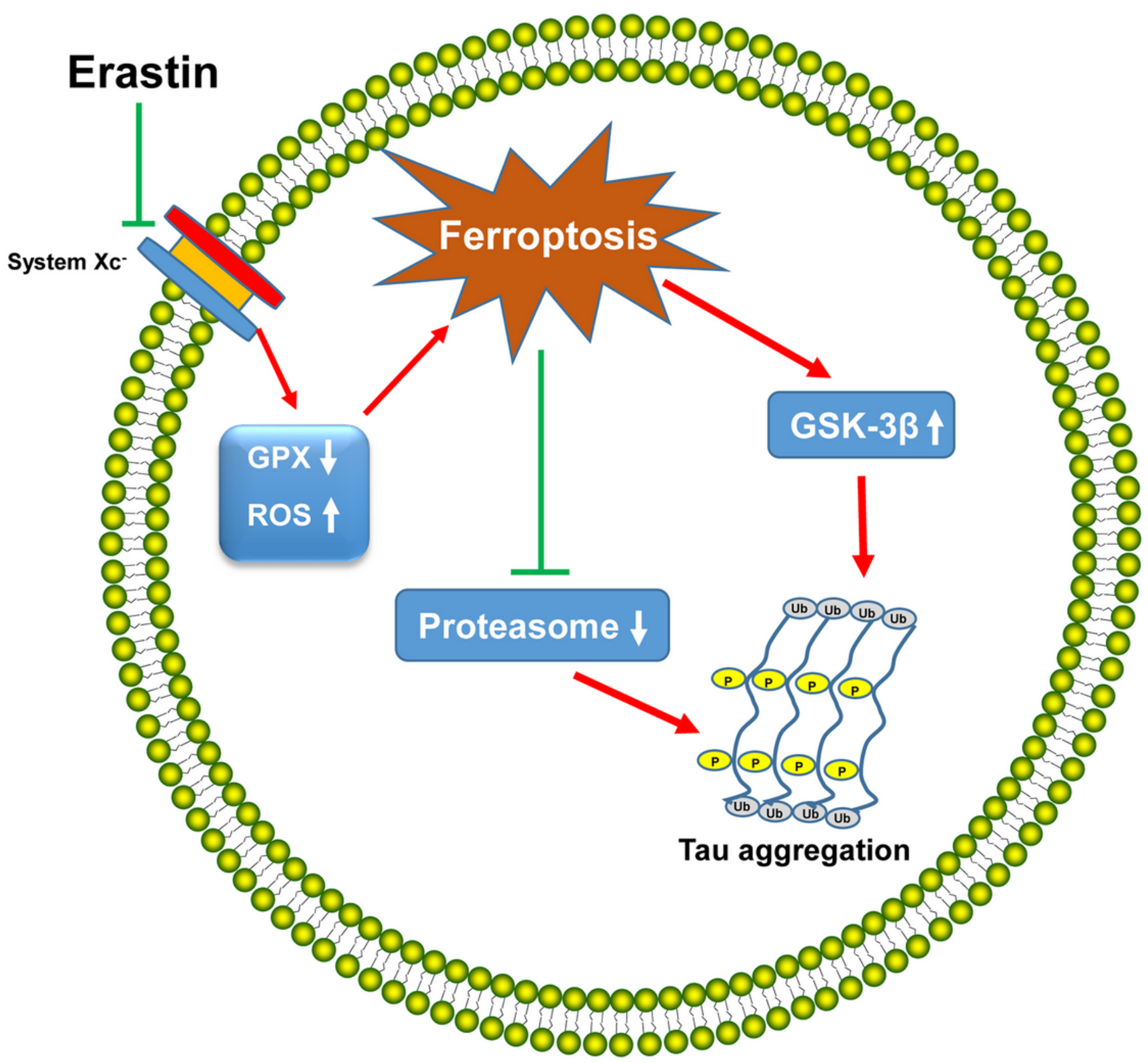

Figure 11

The potential mechanism underlying tau aggregation induced by erastin. Erastin inhibits cystineglutamate antiporter (system Xc-) activity, leads to the GPX activity inhibition and ROS increasing, then triggers the ferroptosis. Ferroptosis can improve the activity of GSK-3 $\beta$, which induces the hyperphosphorylation of tau proteins. Meanwhile, the proteasome system is impaired, which attenuates the degradation efficiency of hyperphosphorylated tau. So the activation of GSK-3 $\beta$ and proteasome impairment might co-contribute to the tau aggregation. 